\title{
Effect of pyrroloquinoline quinone on lipopolysaccharide-induced autophagy in HAPI microglia cells
}

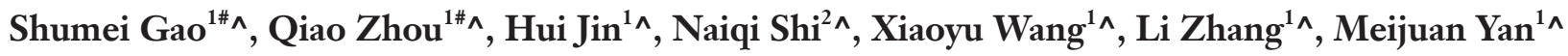 \\ ${ }^{1}$ The Jiangsu Key Laboratory of Neuroregeneration, Nantong University, Nantong, China; ${ }^{2}$ School of Chemistry and Molecular Biosciences, the \\ University of Queensland, Brisbane, Queensland, Australia \\ Contributions: (I) Conception and design: S Gao, Q Zhou, L Zhang, M Yan; (II) Administrative support: None; (III) Provision of study materials or \\ patients: H Jin, N Shi, X Wang; (IV) Collection and assembly of data: H Jin, N Shi, X Wang; (V) Data analysis and interpretation: S Gao, Q Zhou, L \\ Zhang, M Yan; (VI) Manuscript writing: All authors; (VII) Final approval of manuscript: All authors. \\ "These authors contributed equally to this work. \\ Correspondence to: Meijuan Yan; Li Zhang. The Jiangsu Key Laboratory of Neuroregeneration, Nantong University, 19 Qi-xiu Road, Nantong \\ 226001, China. Email: ymz@ntu.edu.cn; zl1115@ntu.edu.cn.
}

Background: Pyrroloquinoline quinone (PQQ) is involved in various physiological and biochemical processes, including antioxidant, cell proliferation, and mitochondrial formation. It plays a vital role in protecting neurons. However, the effect of PQQ on microglia, an inflammatory cell of the central nervous system (CNS), is still unclear. This study aimed to investigate the biological role and neuroprotective mechanism of PQQ in HAPI microglial cells exposed to lipopolysaccharide (LPS).

Methods: Western blot (WB) was used to detect apoptosis and autophagy-related molecules Bax, Bcl2, active-caspase-3, caspase-3, LC3, lysosomal associated membrane protein 2 (LAMP2), AKT, tumor necrosis factor receptor (TNFR) 1, and TNFR2 expression. The phosphatidylinositol 3-kinase (PI3K)/Akt inhibitor LY294002 was used to block the Akt pathway. WB detected the effects of PI3K on autophagy and TNFR1 and TNFR2 expression. The localization of active-caspase-3, caspase-3, LC3, LAMP2, TNFR1, and TNFR2 in cells was observed by immunofluorescence staining. The effect of PQQ on the cell cycle was examined by flow cytometry. We used 5-Ethynyl-2'-deoxyuridine (EdU) assay to detect cell proliferation. The migration ability of cells under different conditions was detected by scratch test and Transwell assay.

Results: Our results showed that there were different effects on the apoptosis-related molecules Bcl2/ Bax and active-caspase-3/caspase in HAPI microglial cells treated with PQQ at different times. PQQ had no significant effect on the LC3b/a ratio in the early stage, which was upregulated in the later stage. The expression of LAMP2 was significantly increased in both early and late stages after PQQ treatment. At the same time, we found that PQQ can reverse the translocation of LAMP2 from the cytoplasm to the nucleus in LPS-induced HAPI microglia. After PQQ treatment, TNFR1 was significantly decreased, but TNFR2 increased in LPS-induced HAPI microglia. It may be that PQQ works through the PI3K/Akt signaling pathway to up-regulate LC3, LAMP2, and TNFR1 and down-regulate TNFR2 in LPS-induced HAPI microglia. However, PQQ has little effect on LPS-induced proliferation, cell cycle, and migration of HAPI microglia.

Conclusions: In LPS-induced HAPI microglia, PQQ reduces the apoptosis level and increases that of autophagy. In addition, PQQ changes the distribution of LAMP2 in the cytoplasm and nucleus, which is regulated through the PI3K/Akt signaling pathway.

Keywords: Pyrroloquinoline quinone (PQQ); apoptosis; autophagy; cell cycle; HAPI microglia

^ORCID: Shumei Gao, 0000-0003-2751-1882; Qiao Zhou, 0000-0002-0445-4742; Hui Jin, 0000-0002-3204-0782; Naiqi Shi, 0000-0001-66115677; Xiaoyu Wang, 0000-0001-9113-5960; Li Zhang, 0000-0002-7014-8858; Meijuan Yan, 0000-0002-6087-969X. 
Submitted Feb 16, 2021. Accepted for publication Jun 04, 2021.

doi: $10.21037 / \mathrm{atm}-21-730$

View this article at: https://dx.doi.org/10.21037/atm-21-730

\section{Introduction}

Pyrroloquinoline quinone (PQQ) is widely distributed throughout the world. It was first reported in gramnegative bacteria in $1979(1,2)$, which is abundant in fruits and vegetables, such as kiwis and green pepper, and has also been detected in human breast milk (3). It is a new lactate dehydrogenase (LDH) coenzyme that affects many physiological and biochemical processes, including antioxidation, promoting cell proliferation, stimulation of mitochondrial formation, and so on $(4,5)$. Most importantly, PQQ deficiency in mice and rats has shown various systemic reactions, including growth disorders, impaired immune response, and reproductive dysfunction (6). Kasahara and Kato asserted that PQQ could become a new B vitamin (7); however, labeling it a mammalian vitamin has been questioned due to the lack of conclusive evidence for the existence of PQQ-dependent enzymes in mammals (8). Despite the controversy surrounding whether PQQ is an essential vitamin in mammals, it has various physiological properties that may be beneficial for human health.

Autophagy is a process in which cytoplasmic components form autophagosomes and then fuse with lysosomes to form autolysosomes, in what is an evolutionally conserved intracellular degradation process (9). After autophagy activation, LC3 a is transformed into LC3b to form an autophagosome, and the ratio of $\mathrm{LC} 3 \mathrm{~b} / \mathrm{a}$ represents the level of autophagy. Autophagy is closely related to apoptosis, and cells block the apoptotic pathway and reduce the apoptotic level through autophagy. The upstream signals of inducing anti-apoptotic $\mathrm{Bcl} 2$ and inhibiting apoptotic Bax have antagonistic effects on each other and activate the downstream caspase-3, leading to apoptosis. Neurodegenerative diseases are associated with autophagy disorders, and drugs that regulate autophagy have been successful in several animal models. Neurodegenerative diseases $(10,11)$, such as Alzheimer's disease (AD) $(12,13)$ or Parkinson's disease (PD) $(14)$, involve the accumulation of protein aggregates in neurons $(15,16)$. Autophagy is activated by inflammatory stimulation in various types of immune cells, in which macrophages are the main phagocytes at the front line of the host's defense. The autophagy activity of macrophages includes phagocytosis associated with MAP1LC3b/LC3 [LC3- associated phagocytosis (LAP)] to promote phagocytosis and degradation $(17,18)$. The toll-like receptors (TLRs), especially TLR4 and TLR7, are used to induce the autophagy of macrophages (19). The TLRs belong to the family of pattern recognition receptors, and activation of TLR signals is crucial for immune cell activation and host defense $(20,21)$. Lipopolysaccharide (LPS)-induced autophagy has also been observed in other cell types, including hepatocytes, cardiomyocytes, and peritoneal mesothelial cells $(22,23)$. Microglia are the main immune cells of the central nervous system (CNS) and are important for normal brain development and homeostasis. Microglia release inflammatory mediators and neurotrophic factors, engulf and degrade microorganisms, as well as phagocyte fragments and apoptotic cells (24). As specialized phagocytes of the brain, microglia can also process other brain-derived materials, including myelin fragments, axons, and synaptic structures, and deposits of proteins such as amyloid-A plaques (25). Microglia respond to damage of the CNS (26) and promote the repair of damage and the restoration of homeostasis in the brain. However, it is expensive and time-consuming to harvest primary microglia for relevant studies, and only a small amount of purified microglia can be obtained. Several immortal cell lines were created as an alternative, such as murine BV-2 cells and rat HAPI microglial cells, which have been widely used in in vitro culture systems. Microglia and macrophages have amazing functional similarities and activation phenotypes, but the autophagy of microglia has been increasingly reported in recent years (27). The LPS molecules are found in the outer membrane of Kelan-negative bacteria, are activated mainly by TLR4, and are widely used in in vitro and in vivo experiments, predominantly to stimulate glial cells (mainly microglia cells). In a recent study, LPS treatment inhibited autophagy of microglial cells and impaired phagocytosis, including MAP1LC3b/LC3-associated phagocytosis (LAP) and clearance, as opposed to LPS causing macrophage autophagy (28). Therefore, LC3 and lysosomal-associated membrane protein 2 (LAMP2) and apoptosis-related proteins $\mathrm{Bax}, \mathrm{Bcl} 2$, active caspase- 3 , and caspase- 3 were detected in this study to clarify the effect of PQQ on LPSinduced apoptosis and autophagy of HAPI microglial cells and the neuroprotective effect of the related mechanisms. 
Tumor necrosis factor- $\alpha(\mathrm{TNF}-\alpha)$ is a highly multipotent cytokine that is a prototypical ligand of the tumor necrosis factor superfamily (TNFSF) and can affect almost any cell type. It triggers a cellular response in which inflammatory genes stimulate cell proliferation and differentiation and activate cell suicide programs such as apoptosis and necrosis. Both TNF receptor 1 (R1) and TNFR2 belong to different subgroups of TNFRSF. As a death receptor (DR), TNFR1 has a death domain (DD) in its cytoplasm (29), which is a conserved type of protein-protein interaction domain that enables DR to interact with cytoplasmic isotype proteins that also have DD (30). The DD signaling proteins link TNFR1 to cytotoxic signaling pathways that trigger apoptosis or necrosis but also activate nuclear factor kappa-B (NF- $\kappa \mathrm{B})$ or the mitogen-activated protein kinase (MAPK) family signaling pathways (31,32). Induced proinflammatory gene signal transduction can be regarded as the default mode of TNFR1 activity.

Conversely, TNFR2 does not have DD (33), so it does not have an intrinsic cell death-inducing activity but stimulates NF- $\kappa \mathrm{B}$ signaling and activation of various kinases (34). Expression of TNFR1 can happen in almost any type of cell. However, TNFR2 expression is limited to certain cell types, including myeloid cells, regulatory $\mathrm{T}$ cells, glial cells, and certain endothelial cell types, but can also be induced in epithelial cells, fibroblasts, and certain T and B cells (35). Although TNF is not constitutively expressed, it is expressed by fibroblasts, endothelial cells, and epithelial cells in response to pro-inflammatory triggers and cytokines, including TNF itself (36). The role of TNF receptors is well known in neurons, and it has been reported that TNFR1 in retinal ischemia enhances neuronal death, while TNFR2 promotes neuroprotection (37). Therefore, it is necessary to investigate the effect of PQQ on the TNFR1 and TNFR2 expression in LPS-induced HAPI microglial cells.

The presence of PQQ is essential for the normal growth and development of animals. For example, PQQ can act as a potential growth factor to promote cell proliferation (38). The PQQ treatment of activated C-Ha-RAS-transformed NIH3T3 cells significantly increased their activity and cell proliferation (39). It has also been reported that PQQ can significantly enhance the proliferation of human epithelial A431 cell lines when the concentration is higher than $10 \mathrm{nM}$ (40). However, there are few reports about the effect of PQQ on LPS-induced microglia. Therefore, in the present study, the effects of PQQ on LPS-induced apoptosis and autophagy of HAPI microglia and the related mechanism of protein kinase $\mathrm{B}(\mathrm{PKB})$ or Akt signaling pathway were investigated to clarify the neuroprotective mechanism of PQQ. We present the following article in accordance with the MDAR reporting checklist (available at https://dx.doi.org/10.21037/atm-21-730).

\section{Methods}

\section{HAPI microglia culture}

The cell resuscitation process was performed as follows: after heating the water temperature to about $37^{\circ} \mathrm{C}$, the frozen HAPI microglial cells (Shanghai Honsun Biological Technology Co., L) were removed from the $-80{ }^{\circ} \mathrm{C}$ refrigerator quickly immersed in the water and stirred to enable rapid thawing. The cell suspension was then transferred from the frozen tube to a $1.5 \mathrm{~mL}$ centrifuge tube and centrifuged at $1,000 \mathrm{r} / \mathrm{min}$ for $5 \mathrm{~min}$. The supernatant was discarded, $2 \mathrm{~mL}$ of 1640 complete medium (10\% fetal bovine serum, 90\% 1640 low-glucose medium) was added and gently pipetted until the cell suspension liquid was obtained. The cell suspension was transferred to a large dish, an appropriate amount of complete medium was added, and it was then placed in a cell incubator.

Cell passaging was conducted as follows: when the cells were in confluency and the density was $90 \%$, cell passaging was performed. The supernatant was discarded, cells were washed once with phosphate-buffered saline (PBS), followed by the addition of trypsin that could not pass through the bottom of the dish. Cells were then placed into the incubator for $40 \mathrm{~s}$, and the cell state was observed. If the antenna was retracted, $2 \mathrm{~mL}$ of complete medium was added to stop the digestion. The bottom of the dish was pipetted to remove the cells and transfer them to a $1.5 \mathrm{~mL}$ centrifuge tube. Centrifugation was conducted at $1,000 \mathrm{r} / \mathrm{min}$ for $5 \mathrm{~min}$; the supernatant was discarded, $2 \mathrm{~mL}$ of complete medium was added, pipetted into a cell suspension, and inoculated at 1:2. This was then placed in the incubator in the same dish.

Cell cryopreservation was performed as follows: the state of the cells was observed, the cryopreservation solution was configured after appropriate cryopreservation, and placed in the refrigerator at $4{ }^{\circ} \mathrm{C}$ to pre-cool. The cells were digested and pipetted into a cell suspension. After centrifugation at $1,000 \mathrm{r} / \mathrm{min}$ for $5 \mathrm{~min}, 1 \mathrm{~mL}$ of pre-chilled cryopreservation solution was added, transferred to a cryopreservation tube, and placed in a refrigerator at $4{ }^{\circ} \mathrm{C}$ for 30 minutes, then $-20^{\circ} \mathrm{C} 2 \mathrm{~h}$, and finally transferred to $-80^{\circ} \mathrm{C}$ refrigerator for storage. 


\section{Cell Counting Kit-8 test}

The HAPI microglial cells were inoculated in a 96-well plate; $100 \mu \mathrm{L}$ of the cell suspension was added to each well and then placed in a cell incubator for pre-cultivation. After the cells had adhered to the wall and were in good condition, they were changed to a complete medium containing different concentrations of PQQ [PQQ was manufactured by Nascent Health Sciences LLC (New York, NY, USA) in its disodium salt form $\left(\right.$ PureQQ $\left.\left.\left.^{\circledR}\right)\right]\right)(0,10,20$, $30,40,50,100 \mu \mathrm{M})$ for $24 \mathrm{~h}$.

We then added $10 \mu \mathrm{L}$ Cell Counting Kit-8 (CCK-8) solution to each well, and observed the color change after incubating for $2 \mathrm{~h}$.

The absorbance was measured at $450 \mathrm{~nm}$ using a microplate reader to calculate cell viability.

\section{Western blot}

The extracted protein was quantified by bicinchoninic acid (BCA) analysis, followed by electrophoresis separation on sodium dodecyl sulfate-polyacrylamide gel electrophoresis (SDS-PAGE). After transferring to a polyvinylidene fluoride (PVDF) membrane (Millipore, Bedford, MA, USA), the membrane was blocked with $5 \%$ non-fat dry milk in Trisbuffered saline (TBS, pH 7.4) and incubated with Rabbitanti-Caspase 3 (1:1,000, ab184787, Abcam, Cambridge, MA, USA), Rabbit-anti-active-Caspase 3 (1:1,000, ab49822, Abcam), Rabbit-anti-Bax (1:1,000, ab12503, Abcam), Rabbit-anti-Bcl2 (1:1,000, NB100-56101, NOVUS), Rabbit-anti-LC3 (1:500, ab128025, Abcam), Rabbit-antiTNFR1 (1:1000, 21574-1-AP, Proteintech, Rosemont, IL, USA), Rabbit-anti-TNFR2 (1:1,000, 19272-1-AP, Proteintech), Rabbit-anti-p-Akt (1:1,000, 8200S, Cell Signaling Technology, Danvers, MA, USA), Rabbit-antiAkt (1:1,000, C67E7, Cell Signaling Technology), Mouseanti- $\beta$-actin $(1: 5,000$, A1978, Sigma-Aldrich, St. Louis, MO, USA), and Rabbit-anti-LAMP2 (1:1,500, L0668, Sigma), respectively, at $4{ }^{\circ} \mathrm{C}$ overnight. After being washed with TBST (TBS with $0.1 \%$ Tween 20) and incubated with an anti-rabbit or anti-mouse horseradish peroxidaseconjugated secondary antibody, the protein was visualized using Beyo ECL Star (Beyotime, Jiangsu, China).

\section{Immunofluorescence staining}

All cell sections were blocked with blocking solution [10\% goat serum, $3 \%$ bovine serum albumin (BSA), $0.1 \%$
Triton X-100] for $30 \mathrm{~min}$ at $37^{\circ} \mathrm{C}$. Then, the sections were incubated with primary antibodies Rabbit-anti-Caspase 3 (1:500, ab184787, Abcam), Rabbit-anti-active-Caspase 3 (1:500, ab49822, Abcam), Rabbit-anti-LC3 (1:100, ab128025, Abcam), Rabbit-anti-TNFR1 (1:400, 21574-1AP, Proteintech), Rabbit-anti-TNFR2 (1:100, 19272-1AP, Proteintech), and Rabbit-anti-LAMP2 (1:400, L0668, Sigma), respectively, at $4{ }^{\circ} \mathrm{C}$ overnight. After being washed with $0.01 \mathrm{M}$ PBS and incubated with a mixture of FITCor $\mathrm{Cy} 3$-conjugated secondary antibodies for $2 \mathrm{~h}$ at room temperature, the stained sections were examined with a Leica fluorescence microscope (Leica DM5000B, Wetzlar, Germany).

\section{Scratch test}

The cells were inoculated into a small dish. After the adherent growth had reached a suitable density, a straight line was drawn along the middle of the dish using a yellow pipette tip. Pre-warmed culture medium was used to clean the fallen cell debris, and then different treatments were added to continue to cultivate. Pictures were taken under the microscope at the different time points of cultivation 0,6 , and $12 \mathrm{~h}$. This whole process was repeated at least 3 times and the data was analyzed.

\section{Migration experiment}

After coating the 24-well plate with Poly-L-lysine (PLL), it was air-dried under an ultraviolet lamp. The cells were divided into the following groups: control group, LPS-only group (1 $\mu \mathrm{g} / \mathrm{mL}$ LPS), PQQ treated groups $(1 \mu \mathrm{g} / \mathrm{mL}$ LPS + $10 \mu \mathrm{M}$ PQQ, $1 \mu \mathrm{g} / \mathrm{mL}$ LPS $+20 \mu \mathrm{M}$ PQQ). We then added $0.5 \mathrm{~mL}$ of the above reagents prepared with 1640 complete medium to 24-well plates, followed by the addition of $100 \mu \mathrm{L}$ of cells resuspended in basal medium to the chamber and cultivate for $24 \mathrm{~h}$. After suctioning the liquid in the chamber, it was fixed with $4 \%$ paraformaldehyde at room temperature for $30 \mathrm{~min}$, followed by staining with crystal violet for $30 \mathrm{~min}$. After washing, the cells in the chamber were gently wiped with a cotton swab. Pictures were then taken under the microscope and statistics were recorded.

\section{5-Ethynyl-2'-deoxyuridine proliferation experiment}

After counting the digested cells, they were placed into a 96-well plate according to the required cell density, this was repeated 3 times for each group, and they were then 
put into a cell incubator for cultivation. After the cells had adhered to other cells, they were inspected and those in good condition were selected for the treatment groups: control group, LPS-only group ( $1 \mu \mathrm{g} / \mathrm{mL}$ LPS), and 2 PQQ treated groups $(1 \mu \mathrm{g} / \mathrm{mL}$ LPS $+10 \mu \mathrm{M}$ PQQ, $1 \mu \mathrm{g} / \mathrm{mL}$ LPS + $20 \mu M$ PQQ), and placed into a cell incubator for 24 h. The 5-Ethynyl-2'-deoxyuridine (EdU) solution (reagent A) was diluted with the medium at 1:1,000, an appropriate amount of $50 \mu \mathrm{M}$ EdU solution was prepared, $100 \mu \mathrm{l}$ was added to each well, and incubated for $2 \mathrm{~h}$. The supernatant was discarded followed by washing twice with PBS. Cell fixation was performed as follows: (I) $100 \mu \mathrm{L} /$ well of $4 \%$ paraformaldehyde was added and incubated at room temperature for $30 \mathrm{~min}$, after which the supernatant was discarded. (II) A total of $50 \mu \mathrm{L} /$ well of $2 \mathrm{mg} / \mathrm{mL}$ glycine was added, decolorized and incubated for $5 \mathrm{~min}$, and the supernatant was discarded. (III) A total of $100 \mu \mathrm{L} /$ well was added, washed with PBS for $5 \mathrm{~min}$, and the supernatant was discarded. (IV) Incubation with $100 \mu \mathrm{L} /$ well penetrant for $10 \mathrm{~min}$, followed by a single wash with PBS for $5 \mathrm{~min}$. (V) The staining was conducted as follows: (i) $100 \mu \mathrm{L} /$ well of $1 \times$ Apollo staining solution was added, incubated at room temperature in the dark for $30 \mathrm{~min}$, and the supernatant was discarded. (ii) $100 \mu \mathrm{L} /$ well of penetrant was washed 3 times for 10 min each time, and the supernatant was discarded. (iii) $100 \mu \mathrm{L} /$ well were washed twice with methanol for $5 \mathrm{~min}$ each time and then with PBS 5 min each time. (VI) Staining of the nucleus was carried out as follows: Reagent $\mathrm{F}$ was diluted in proportion with deionized water, an appropriate amount of Hoechst33342 working solution (Thermo Fisher) was prepared, $100 \mu \mathrm{L}$ Hoechst 33342 working solution was added to each well, they were then incubated at room temperature for $30 \mathrm{~min}$ in the dark, and placed on a shaker. (VII) Washing with PBS was repeated 3 times for 10 min each time. (VIII) Photos were taken immediately after the dyeing.

\section{Flow cytometry to detect cell cycle}

(I) The cells were digested as follows: after centrifugation at $12,000 \mathrm{r} / \mathrm{min} \times 5 \mathrm{~min}$, supernatant was discarded, $1 \mathrm{~mL}$ of cold PBS was added, cells were resuspended, transferred to a $1.5 \mathrm{~mL}$ centrifuge tube, centrifuged at $12,000 \mathrm{r} / \mathrm{min} \times$ 5 min, supernatant discarded, and the bottom of the tube was flicked to disperse the cells. (II) For cell fixation, we added $1 \mathrm{~mL}$ of pre-cooled $70 \%$ ethanol, mixed it well, and placed it in refrigerator at $4{ }^{\circ} \mathrm{C}$ for $2 \mathrm{~h}(12-24 \mathrm{~h}$ was preferred). The solution was then centrifuged at $12,000 \mathrm{r} / \mathrm{min} \times 5 \mathrm{~min}$, the supernatant was discarded, $1 \mathrm{~mL}$ pre-chilled PBS was added, cells were resuspended, centrifuged at $12,000 \mathrm{r} / \mathrm{min} \times 5 \mathrm{~min}$, and the supernatant was discarded. (III) The propidium iodide (PI) staining solution (single sample) was prepared stored at $4{ }^{\circ} \mathrm{C}$, and used on the same day. (IV) Staining was conducted as follows: $0.5 \mathrm{~mL}$ PI staining solution was added to each tube of cells, the cells were slowly and fully resuspended, kept at $37^{\circ} \mathrm{C}$ in the dark for $30 \mathrm{~min}$, then stored at $4{ }^{\circ} \mathrm{C}$ or in an ice bath protected from light, and tested within $24 \mathrm{~h}$ after staining. (V) Flow cytometry was used to detect red fluorescence at the excitation wavelength of $488 \mathrm{~nm}$ and the cells were analyzed it using MFLT32 software (Verity Software House, 45A Augusta Road, Topsham, ME 04086-5710 USA).

\section{Transmission electron microscope}

(I) HAPI microglial cells were cultured to a suitable density and divided into the control group, LPS-only group (1 $\mu \mathrm{g} / \mathrm{mL}$ LPS), and the 2 PQQ treated groups. The cells were incubated for $24 \mathrm{~h}$. First, the culture solution in the culture bottle or dish was discarded, and the cells were rinsed with room temperature PBS or physiological saline. (II) A cell scraper was used to gently scrape all cells from the tube wall or the bottom of the dish. After collecting the cells in a $1.5 \mathrm{~mL}$ centrifuge tube, the supernatant was removed, a pre-cooled glutaraldehyde solution was gently added, and the cells were rested at $4{ }^{\circ} \mathrm{C}$ for $2 \mathrm{~h}$ (Note: the experiment required that a $1.5 \mathrm{~mL}$ centrifuge tube be used to collect the cells; when glutaraldehyde was added, the cell clumps were not dispersed and resuspended, otherwise it would have been difficult to centrifuge the cells again into a pellet). (III) The supernatant was discarded, the centrifuge tube was tilted, and an appropriate amount of $40{ }^{\circ} \mathrm{C} 1-2 \%$ agar solution was gently added near the wall of the cell mass. After the Cell clumps that had solidified with the agar were gently picked out, and placed in the fixative again. Samples were then sent and pictures were taken.

\section{Statistical methods}

All data were analyzed using the software GraphPad Prism8 $8^{\circledR}$ 8.0.2 (263) (GraphPad Software, Inc., San Diego, CA, USA). Quantitative data were expressed as mean \pm standard error $(\bar{x} \pm \mathrm{s})$. The data comparison between the 2 groups was performed by $t$-test. For comparison of data among 3 or more groups, one-way analysis of variance (ANOVA) was used. A $\mathrm{P}$ value $<0.05$ indicated statistical 


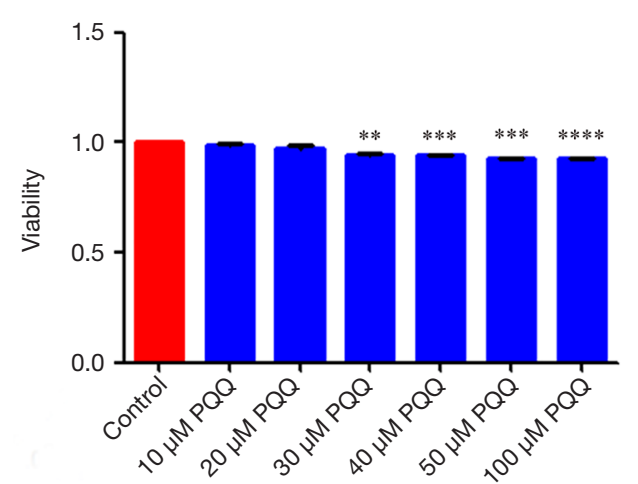

Figure 1 CCK-8 test of the viability of HAPI microglia treated with PQQ at different concentrations for $24 \mathrm{~h}$. Compared with control group, ${ }^{* *} \mathrm{P}<0.01,{ }^{* * *} \mathrm{P}<0.001,{ }^{* * * *} \mathrm{P}<0.0001$. CCK-8, Cell Counting Kit-8; PQQ, pyrroloquinoline quinone.

significance. Each experiment was repeated at least 3 times under the same conditions. Adobe Photoshop 9.3 (Adobe, San Jose, CA, USA) and ImageJ (National Institutes of Health, Bethesda, MD, USA) were used to process images.

\section{Results}

\section{Toxic effects of $P Q Q$ at different concentrations on $H A P I$ microglial cells}

To investigate the toxicity of PQQ, the HAPI microglia were treated with $P Q Q$ at different concentrations $(10,20,30,40,50,100 \mu \mathrm{M})$ for $24 \mathrm{~h}$, and the untreated group was set as the control group. Cell activity was measured using the CCK-8 kit, and the results are shown in Figure 1. Compared with the control group, PQQ $\geq 30 \mu \mathrm{M}$ at all concentrations had an inhibitory effect on cell activity (all $\mathrm{P}<0.05$ ), indicating that the high concentration of PQQ had certain cytotoxicity. Therefore, 10 and $20 \mu \mathrm{M}$ concentrations were selected for subsequent experiments.

\section{Effects of different concentrations of $P Q Q$ on apoptosis of HAPI microglia treated by LPS}

As a classic inflammatory factor, LPS is often used to create inflammation models in vivo and in vitro. Western blot (WB) was used to detect the changes in the ratio of Bcl2/ Bax related to apoptosis of LPS-induced HAPI microglia by PQQ. As shown in Figure 2, at 3 h, compared with the LPS-only group, the Bcl2/Bax ratio of both PQQ treatment groups decreased, and there was a statistically significant difference among groups $(\mathrm{P}<0.05)$; at $12 \mathrm{~h}$, the difference

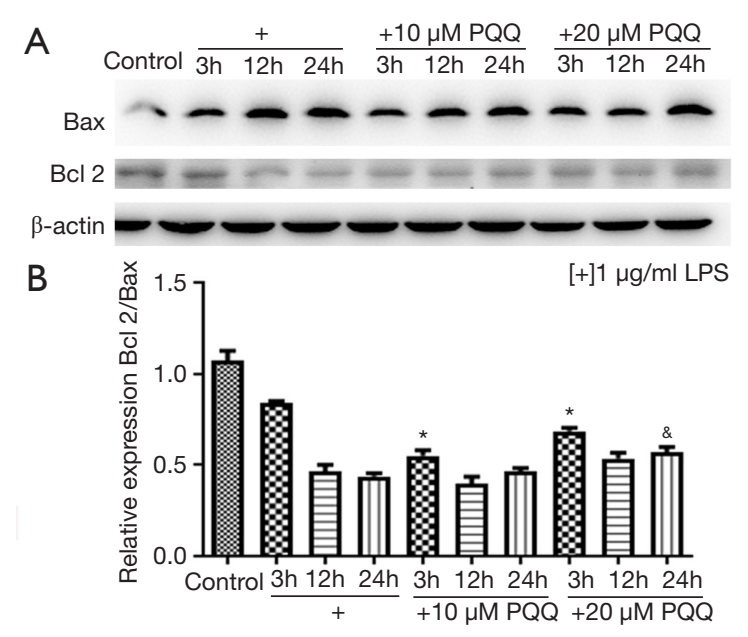

Figure 2 Expression of Bcl2/Bax in HAPI microglia after PQQ treatment. (A) WB detection of Bax, Bcl2 protein expression; (B) the statistical graph of $\mathrm{Bcl} 2 / \mathrm{Bax}$ relative expression. (A and $\mathrm{B}$ ) from left to right are the control group (untreated), $1 \mu \mathrm{g} / \mathrm{mL}$ LPS treatment for $3 \mathrm{~h}, 1 \mu \mathrm{g} / \mathrm{mL}$ LPS treatment for $12 \mathrm{~h}, 1 \mu \mathrm{g} / \mathrm{mL} \mathrm{LPS}$ treatment for $24 \mathrm{~h}, 1 \mu \mathrm{g} / \mathrm{mL}$ LPS $+10 \mu \mathrm{M}$ PQQ treatment for $3 \mathrm{~h}, 1 \mu \mathrm{g} / \mathrm{mL}$ LPS + $10 \mu \mathrm{M}$ PQQ treatment for $12 \mathrm{~h}, 1 \mu \mathrm{g} / \mathrm{mL}$ LPS + $10 \mu \mathrm{M}$ PQQ treatment for $24 \mathrm{~h}, 1 \mu \mathrm{g} / \mathrm{mL} \mathrm{LPS}+20 \mu \mathrm{M}$ PQQ treatment $3 \mathrm{~h}, 1 \mu \mathrm{g} / \mathrm{mL}$ LPS $+20 \mu \mathrm{M}$ PQQ treatment for $12 \mathrm{~h}, 1 \mu \mathrm{g} / \mathrm{mL}$ LPS + $20 \mu \mathrm{M}$ PQQ treatment for $24 \mathrm{~h} ;{ }^{*} \mathrm{P}<0.05$ vs. $1 \mu \mathrm{g} / \mathrm{mL}$ LPS for $3 \mathrm{~h} ;{ }^{*} \mathrm{P}<0.05$ vs. $1 \mu \mathrm{g} / \mathrm{mL}$ LPS treatment for 24 h. PQQ, pyrroloquinoline quinone; WB, western blot; LPS, lipopolysaccharide.

was not statistically significant $(\mathrm{P}>0.05)$; at $24 \mathrm{~h}$, the $\mathrm{Bcl} 2 /$ Bax ratio of the PQQ treatment group increased, and the difference was statistically significant $(\mathrm{P}<0.05)$. It showed that PQQ had different effects at different times: PQQ had a proapoptotic effect on HAPI microglia treated with LPS in the early stage but had an anti-apoptotic effect in the later stage.

Secondly, the expression changes of the active-Caspase 3/Caspase 3 ratios of apoptotic markers in LPS-induced HAPI microglia were detected by WB. As shown in Figure $3 A, 3 B$, there was no significant difference in active-Caspase 3/Caspase 3 ratios between the PQQ-treated group at $3 \mathrm{~h}$ compared with the LPS-only group (all $\mathrm{P}>0.05$ ). At $12 \mathrm{~h}$, the active-Caspase 3/Caspase 3 ratio was reduced in both PQQ treatment groups, but the reduction effect in the $10 \mu \mathrm{M}$ PQQ treatment group was less obvious than that in the $20 \mu \mathrm{M}$ PQQ treatment group $(\mathrm{P}<0.05)$. At $24 \mathrm{~h}$, compared with the LPS-only group, the ratio of active-Caspase 3/ Caspase 3 in the PQQ group was significantly decreased (all $\mathrm{P}>0.05)$. This indicated that PQQ reduced LPS-induced death 


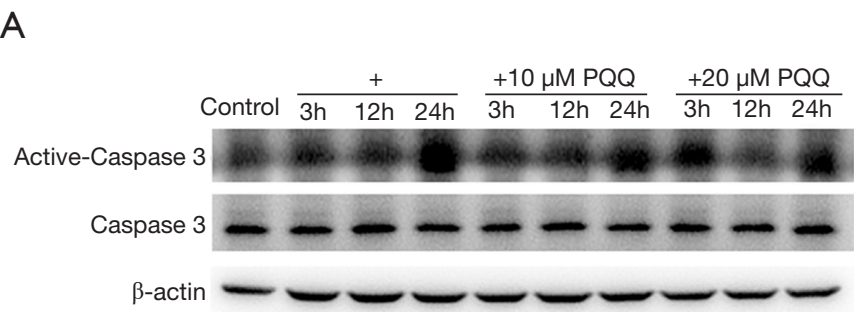

$[+] 1 \mu \mathrm{g} / \mathrm{ml}$ LPS

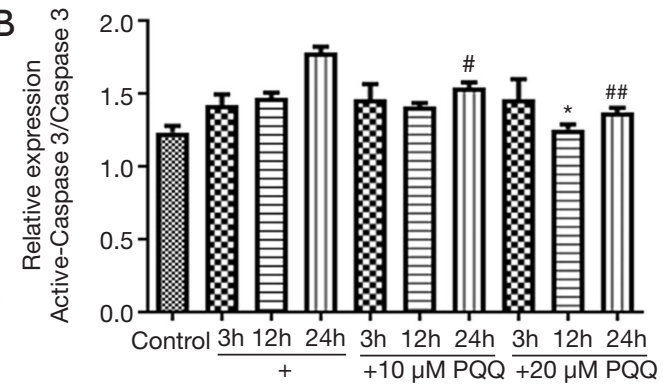

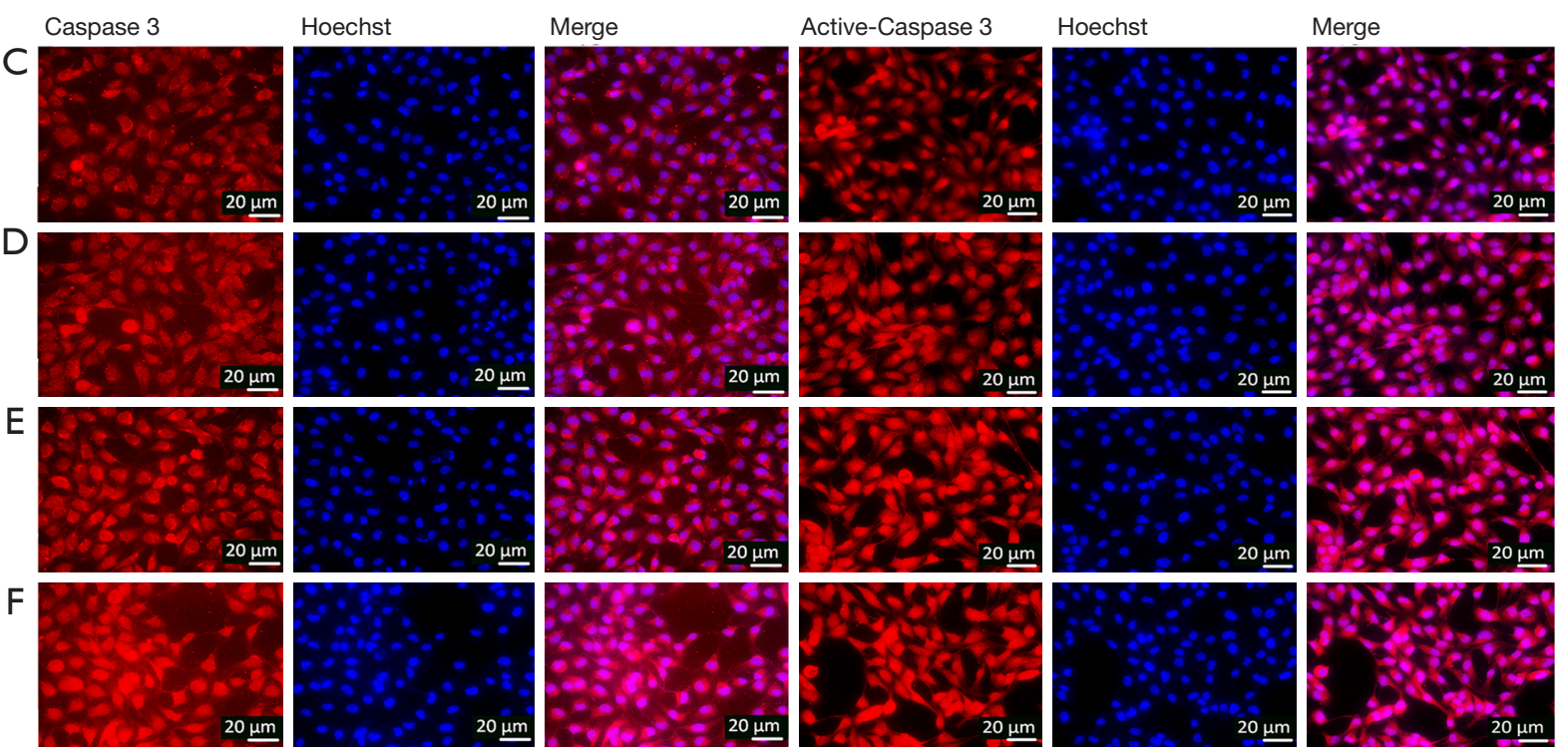

Figure 3 Expression of Active-Caspase 3/Caspase 3 in HAPI microglia. (A) WB detection of the protein expression of Active-Caspase 3 and Caspase 3; (B) the statistical graph of Active-Caspase3/Caspase3. +: $1 \mu \mathrm{g} / \mathrm{mL}$ LPS; A and B from left to right are the control group (untreated), $1 \mu \mathrm{g} / \mathrm{mL}$ LPS treatment for $3 \mathrm{~h}, 1 \mu \mathrm{g} / \mathrm{mL}$ LPS treatment for $12 \mathrm{~h}, 1 \mu \mathrm{g} / \mathrm{mL}$ LPS treatment for $24 \mathrm{~h}, 1 \mu \mathrm{g} / \mathrm{mL}$ LPS + $10 \mu M$ PQQ treatment for $3 \mathrm{~h}, 1 \mu \mathrm{g} / \mathrm{mL}$ LPS + $10 \mu \mathrm{M}$ PQQ treatment for $12 \mathrm{~h}, 1 \mu \mathrm{g} / \mathrm{mL}$ LPS + $10 \mu \mathrm{M}$ PQQ treatment for $24 \mathrm{~h}, 1 \mu \mathrm{g} / \mathrm{mL} \mathrm{LPS}+20 \mu \mathrm{M}$ PQQ treatment $3 \mathrm{~h}, 1 \mu \mathrm{g} / \mathrm{mL}$ LPS + $20 \mu \mathrm{M}$ PQQ treatment for $12 \mathrm{~h}, 1 \mu \mathrm{g} / \mathrm{mL}$ LPS + $20 \mu \mathrm{M}$ PQQ treatment for $24 \mathrm{~h} ;{ }^{*} \mathrm{P}<0.05 v s .1 \mu \mathrm{g} / \mathrm{mL} \mathrm{LPS}$ treatment for $12 \mathrm{~h} ;{ }^{\#} \mathrm{P}<0.05$ vs. $1 \mu \mathrm{g} / \mathrm{mL}$ LPS treatment for $24 \mathrm{~h} ;{ }^{\# \#} \mathrm{P}<0.01$ vs. $1 \mu \mathrm{g} / \mathrm{mL}$ LPS treatment for $24 \mathrm{~h}$. (C-F) Immunofluorescence assay of Caspase 3 and Active-Caspase 3 expression in HAPI microglia: (C) control group; (D) $1 \mu \mathrm{g} / \mathrm{mL}$ LPS only group; (E) $1 \mu \mathrm{g} / \mathrm{mL}$ LPS + $10 \mu \mathrm{M}$ PQQ group; (F) $1 \mu \mathrm{g} / \mathrm{mL}$ LPS + $20 \mu \mathrm{M}$ PQQ group. Caspase 3, Active-Caspase 3 (red); Hoechst (blue); Merge (combined picture); bar $=20 \mu \mathrm{m}$. PQQ, pyrroloquinoline quinone; WB, western blot; LPS, lipopolysaccharide.

of HAPI microglia. These results are not completely consistent with the expression trend of the Bcl2/Bax ratio, possibly due to their presence in different sites in the apoptotic pathway.

The results of $\mathrm{WB}$ showed significant changes in activeCaspase 3/Caspase 3 in the $24 \mathrm{~h}$ treatment group, the specific distribution of active-Caspase 3 and Caspase 3 in HAPI microglia cells was further observed in the $24 \mathrm{~h}$ treatment group. Immunofluorescence staining results showed that active-Caspase 3 was expressed in HAPI microglial plasma and nucleus, and it was mainly localized in the nucleus. There were no statistically significant differences in cell expression and localization between each group $(\mathrm{P}>0.05)$ (Figure $3 C-3 F)$. These results indicated that PQQ had no significant effect on the expression and localization of active-Caspase 3 in HAPI microglia.

Unlike active-Caspase 3, Caspase 3 was mainly located in the HAPI microglia cytoplasm in the control group, while it was widely distributed in the nucleus and cytoplasm in the LPS-only group. The PQQ treatment groups $(1 \mu \mathrm{g} / \mathrm{mL}$ LPS + $10 \mu \mathrm{M}$ PQQ, $1 \mu \mathrm{g} / \mathrm{mL}$ LPS + $20 \mu \mathrm{M}$ PQQ) caused Caspase 3 to translocate from the nucleus to the cytoplasm (Figure $3 C-3 F$ ). These results suggest that PQQ can reverse 
the translocation of LPS-induced Caspase 3 from the cytoplasm to the nucleus.

\section{Effects of PQQ on LC3 and LAMP 2 expression in LPS-induced HAPI microglia}

To observe the effect of PQQ on autophagy of LPSinduced HAPI microglial cells, LC3 was used as a marker of autophagy, and the level of LC3b/a represented the level of autophagy. The results of WB showed that there was no significant difference in LC3b/a ratio between the PQQ treatment groups at $3 \mathrm{~h}$ (all $\mathrm{P}>0.05$ ). At 12 and $24 \mathrm{~h}$, the $\mathrm{LC} 3 \mathrm{~b} / \mathrm{a}$ ratio was increased in the PQQ treatment groups, and the difference was statistically significant (all $\mathrm{P}<0.05$ ), as shown in Figure 4A,4B. This indicated that PQQ has little effect on autophagy in the early stage and promotes autophagy in the later stage.

As the expression level of autophagy marker LC3 in HAPI microglia changed after PQQ treatment changed, we investigated the expression level of LAMP2, a marker of lysosomes interacting with autophagosomes. The results of WB showed that LAMP 2 expression in the PQQ treatment groups was significantly up-regulated at $3 \mathrm{~h}$ compared with the LPS group, and the differences were statistically significant (all $\mathrm{P}<0.05)$. There was no significant difference in the $12 \mathrm{~h}$ treatment group $(\mathrm{P}>0.05)$. At $24 \mathrm{~h}$, compared with the LPS group, LAMP2 was up-regulated only in the $1 \mu \mathrm{g} / \mathrm{mL}$ LPS $+20 \mu \mathrm{M}$ PQQ group, and the difference between these 2 groups was statistically significant $(\mathrm{P}<0.05)$, as shown in Figure 4C,4D.

The results of WB showed that the autophagy level changed $24 \mathrm{~h}$ after PQQ treatment. Therefore, immunofluorescence staining was used to detect the expression of LC3 in cells after $24 \mathrm{~h}$ of PQQ treatment. The results showed that LC3 was mainly localized in the nucleus and distributed concentratedly, but there was no significant difference in the location of cells in each group (Figure 4E-4H).

The results of WB showed that the expression level of LAMP2 changed significantly in the PQQ treatment groups at $3 \mathrm{~h}$. To understand the specific role of LAMP2, this study used immunofluorescence to observe LAMP2 localization in HAPI microglial cells after PQQ treatment for $3 \mathrm{~h}$. In the control group, LAMP2 was widely distributed in the nucleus and cytoplasm. In contrast, in the LPS-only group, LAMP2 was mainly concentrated in the nucleus and was distributed in both the nucleus and cytoplasm of the $1 \mu \mathrm{g} / \mathrm{mL}$ LPS + $10 \mu \mathrm{M}$ PQQ group (Figure 4I-4K), suggesting that PQQ could reverse the translocation of LAMP2 from the cytoplasm to the nucleus in LPS-induced HAPI microglia.

\section{Effect of PQQ on autophagosomes of LPS-induced HAPI microglia}

We used electron microscopy to observe better the changes of autophagosome after LPS stimulation of HAPI microglia. As shown in Figure 5A-5D, autophagy was not detected in the control group, but multiple autophagosomes were found in the LPS-only group and PQQ treatment groups. Also, we found that the endoplasmic reticulum stress response was significant in the LPS-only group, but not in the PQQ treatment groups. It was suggested that PQQ could reduce the damage of LPS-induced HAPI microglia, as shown in Figure 5A'-5D'.

\section{Effect of PQQ on LPS-induced TNFR1 and TNFR2 expression in HAPI microglial cells}

It has been shown that LPS can induce the expression level of TNF- $\alpha$ in microglia and astrocytes, and TNF- $\alpha$ plays its role through TNFRs. The TNFRs consist of TNFR1 and TNFR2. Therefore, WB was used in this study to detect the expression changes of TNFR1 and TNFR2 in HAPI microglia. At $3 \mathrm{~h}$, there was no significant difference in TNFR1 expression between the PQQ-treated groups compared with the LPS-only group (all $\mathrm{P}>0.05$ ). At 12 and 24 h, TNFR1 expression was significantly decreased in the PQQ treatment groups, and the differences were statistically significant (all $\mathrm{P}<0.05$ ), as shown in Figure $6 A, 6 B$.

As shown in Figure 6A',6B', TNFR2 expression was decreased at 3 and $12 \mathrm{~h}$ in PQQ-treated groups, compared with the LPS-only group, and the difference was statistically significant $(\mathrm{P}<0.05)$. In contrast, TNFR2 expression was significantly increased in the $1 \mu \mathrm{g} / \mathrm{mL}$ LPS $+20 \mu \mathrm{M}$ PQQ group at $24 \mathrm{~h}$, and the difference was statistically significant $(\mathrm{P}<0.05)$.

The results of WB revealed obvious changes of TNFR1 and TNFR2 after $24 \mathrm{~h}$ treatment. Therefore, immunofluorescence staining was used to detect the localization of TNFR1 and TNFR2 in cells after $24 \mathrm{~h}$ treatment. The results showed that TNFR1 was expressed in both nucleus and cytoplasm of the control group, was mainly localized in the nucleus in the $1 \mu \mathrm{g} / \mathrm{mL}$ LPS group, and was widely distributed in the nucleus and cytoplasm PQQ-treated groups, as shown in Figure 6C-6F, suggesting that PQQ could reverse the transposition of TNFR1 from the cytoplasm to the nucleus in LPS-induced HAPI 
A

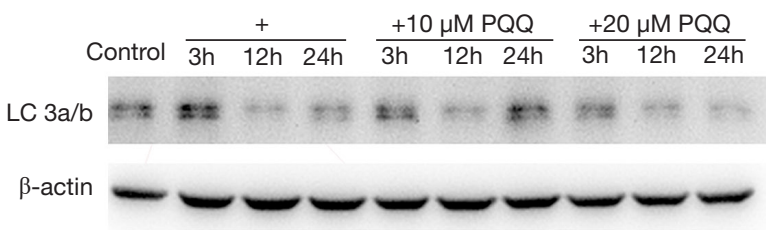

$[+] 1 \mu \mathrm{g} / \mathrm{ml}$ LPS

C Control $\frac{+}{3 \mathrm{~h} 12 \mathrm{~h} \mathrm{24h}} \frac{+10 \mu \mathrm{M} \mathrm{PQQ}}{3 \mathrm{~h} 12 \mathrm{~h} 24 \mathrm{~h}} \frac{+20 \mu \mathrm{M} \mathrm{PQQ}}{3 \mathrm{~h} 12 \mathrm{~h} \mathrm{24h}}$ LAMP 2

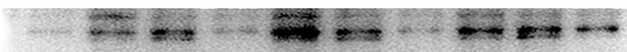

$\beta$-actin

$[+] 1 \mu \mathrm{g} / \mathrm{ml}$ LPS

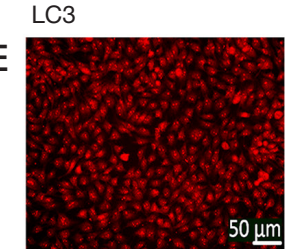

Hoechst

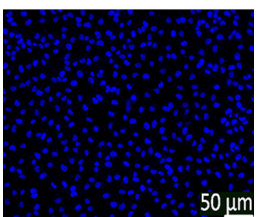

$\mathrm{F}$

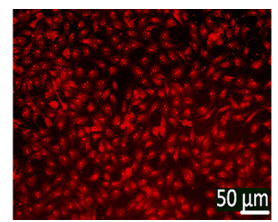

G

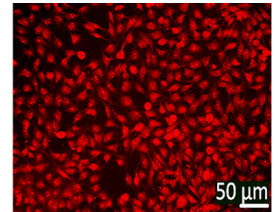

$\mathrm{H}$

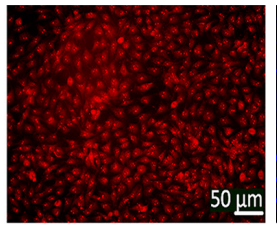

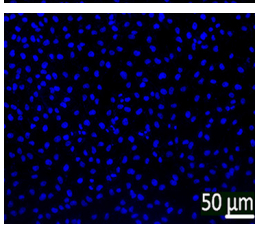
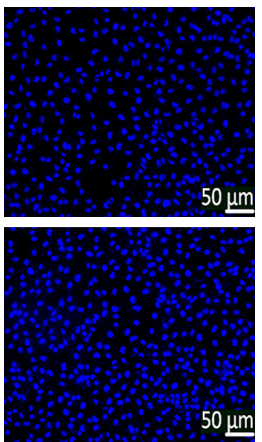

Merge
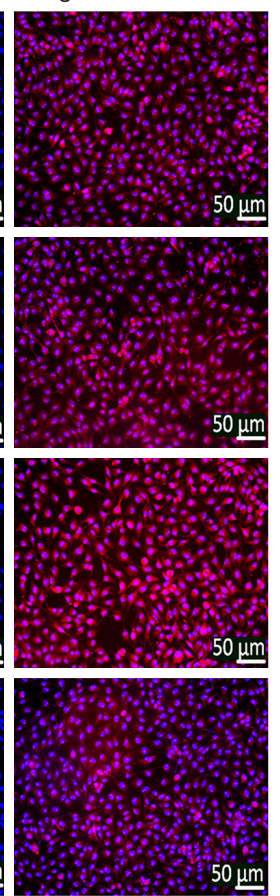

B
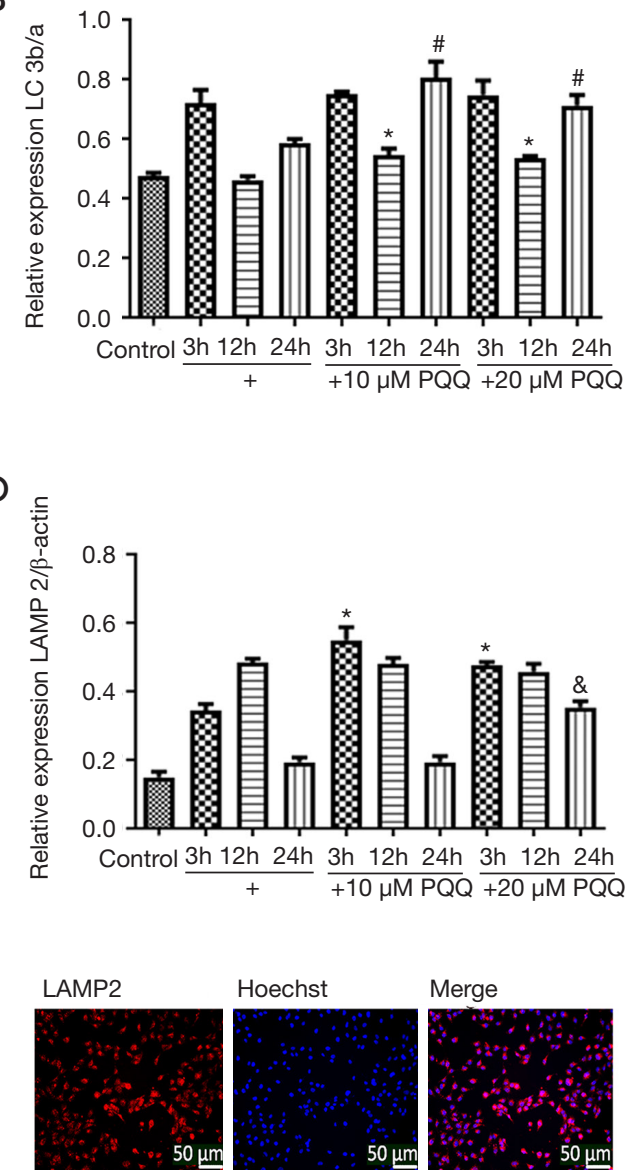

Hoechst

\section{Merge}
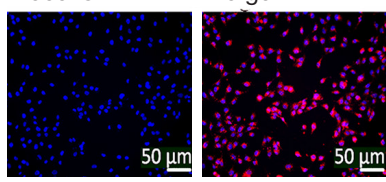

J
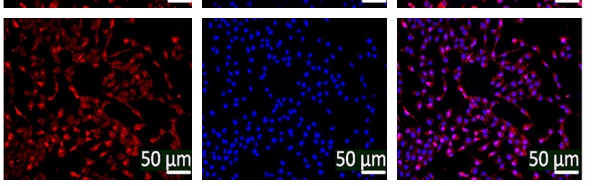

$\mathrm{K}$
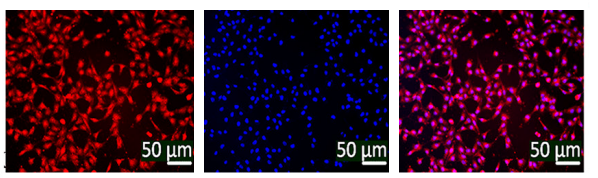

Figure 4 Expression of LC3 in HAPI microglia. (A) WB detection of the expression of LC3 protein in different groups; (B) statistical graph of LC3b/a. (C) WB detection of the expression of LAMP2 protein in different groups; (D) statistical graph of LAMP2. +: $1 \mu \mathrm{g} / \mathrm{mL}$ LPS; A-B from left to right are the control group (untreated), $1 \mu \mathrm{g} / \mathrm{mL}$ LPS treatment for $3 \mathrm{~h}, 1 \mu \mathrm{g} / \mathrm{mL}$ LPS treatment for $12 \mathrm{~h}, 1 \mu \mathrm{g} / \mathrm{mL}$ LPS treatment for $24 \mathrm{~h}, 1 \mu \mathrm{g} / \mathrm{mL}$ LPS + $10 \mu \mathrm{M}$ PQQ treatment for $3 \mathrm{~h}, 1 \mu \mathrm{g} / \mathrm{mL}$ LPS + $10 \mu \mathrm{M}$ PQQ treatment for $12 \mathrm{~h}, 1 \mu \mathrm{g} / \mathrm{mL}$ LPS + $10 \mu \mathrm{M}$ PQQ treatment for $24 \mathrm{~h}, 1 \mu \mathrm{g} / \mathrm{mL}$ LPS + $20 \mu \mathrm{M}$ PQQ treatment $3 \mathrm{~h}, 1 \mu \mathrm{g} / \mathrm{mL}$ LPS + $20 \mu \mathrm{M}$ PQQ treatment for $12 \mathrm{~h}, 1 \mu \mathrm{g} / \mathrm{mL}$ LPS + $20 \mu \mathrm{M}$ PQQ treatment for $24 \mathrm{~h}$; ${ }^{*} \mathrm{P}<0.05$ vs. $1 \mu \mathrm{g} / \mathrm{mL}$ LPS treatment for $12 \mathrm{~h},{ }^{\#} \mathrm{P}<0.05$ vs. $1 \mu \mathrm{g} / \mathrm{mL}$ LPS for $24 \mathrm{~h},{ }^{8} \mathrm{P}<0.05 v s .1 \mu \mathrm{g} / \mathrm{mL}$ LPS for $24 \mathrm{~h}$; (E-H) immunofluorescence detection of LC3 expression in HAPI microglia. (E) control group; (F) $1 \mu \mathrm{gg} / \mathrm{mL}$ LPS; (G) $1 \mu \mathrm{g} / \mathrm{mL}$ LPS + $10 \mu \mathrm{M}$ PQQ; (H) $1 \mu \mathrm{g} / \mathrm{mL}$ LPS + $20 \mu \mathrm{M}$ PQQ; LC3 (red); Hoechst (blue); Merge (combined graph); bar =50 $\mu \mathrm{m}$. (I-K) Immunofluorescence detection of LAMP2 expression in HAPI microglia. (I) control group; (J) $1 \mu \mathrm{g} / \mathrm{mL}$ LPS; (K) $1 \mu \mathrm{g} / \mathrm{mL}$ LPS $+10 \mu M$ PQQ. LAMP 2 (red); Hoechst (blue); Merge (combined picture); bar =50 $\mu \mathrm{m}$. PQQ, pyrroloquinoline quinone; WB, western blot; LPS, lipopolysaccharide. 

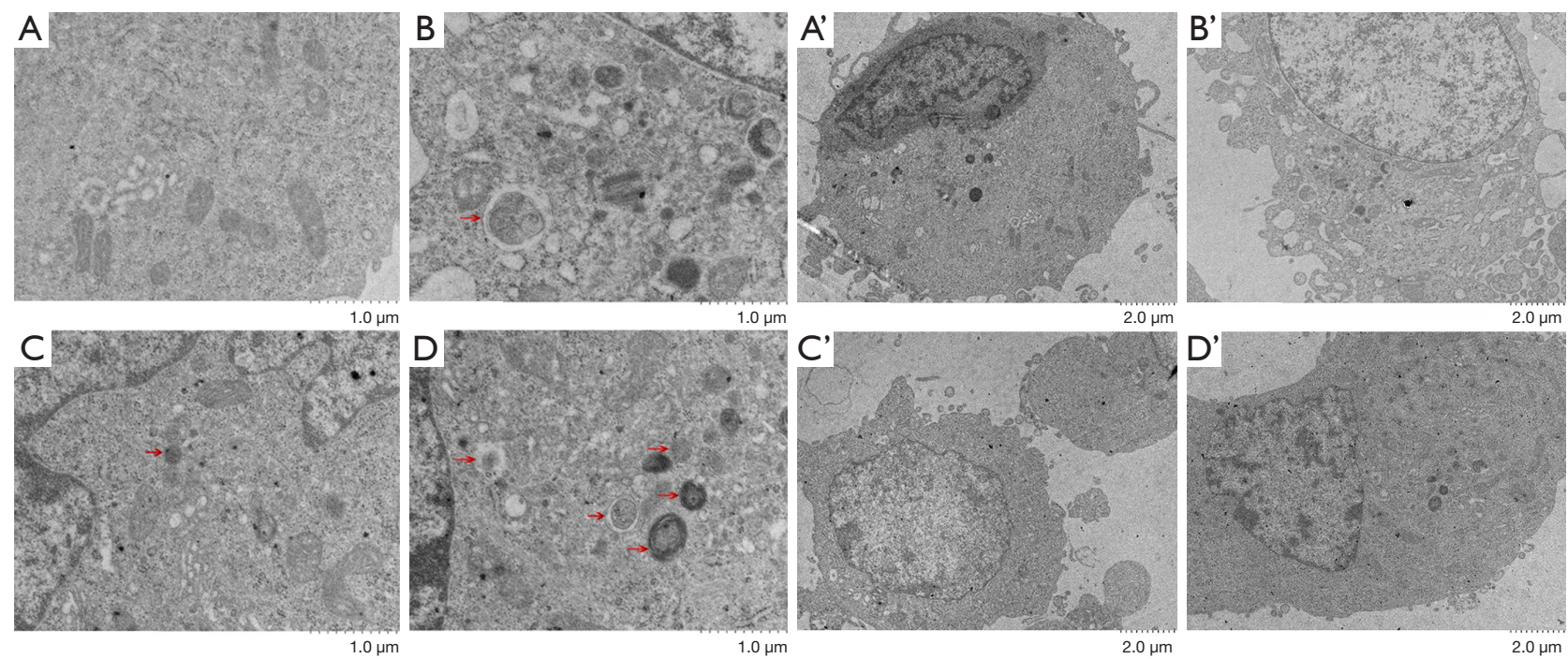

Figure 5 Transmission electronic microscopy photomicrographs in HAPI microglia. (A-D) autophagosomes (arrows); (A'-D') endoplasm. (A,A') control group; (B,B') $1 \mu \mathrm{g} / \mathrm{mL}$ LPS; (C,C') $1 \mu \mathrm{g} / \mathrm{mL}$ LPS + $10 \mu \mathrm{M}$ PQQ; (D,D') $1 \mu \mathrm{g} / \mathrm{mL}$ LPS + $20 \mu M$ PQQ. Bar =1 $\mu \mathrm{m}$. PQQ, pyrroloquinoline quinone; LPS, lipopolysaccharide.

microglia. However, TNFR2 was distributed in both the nucleus and cytoplasm of HAPI microglia, and there was no significant difference in localization among different groups, as shown in Figure 6C'-6F'.

\section{Effect of PQQ on Akt expression in LPS-induced HAPI microglia}

Akt is involved in the activation of microglia cells by LPS. As a classical signaling pathway, the PI3K-Akt signaling pathway is involved in regulating cell growth, proliferation, cycle, apoptosis, and other aspects. It was shown through WB that the phosphorylation level of Akt (P-Akt/Akt) increased over time during LPS stimulation of HAPI microglia. Compared with the $1 \mu \mathrm{g} / \mathrm{mL}$ LPS group, p-Akt/Akt expressions in the PQQ-treated groups were up-regulated at 3, 12, and $24 \mathrm{~h}$ and the differences were statistically significant (all $\mathrm{P}<0.05$ ), as shown in Figure 7 A.

To investigate whether the Akt signaling pathway plays a role in the process, the Akt inhibitor LY294002 was used to inhibit Akt activity, and the expression changes of LC3, LAMP2, TNFR1, and TNFR2 in cells were detected by WB. As shown in Figure $7 B, 7 C, \mathrm{LC} 3$ and LAMP2 expression in the $1 \mu \mathrm{g} / \mathrm{mL}$ LPS + $10 \mu \mathrm{M}$ LY294002 group were lower than those in the $1 \mu \mathrm{g} / \mathrm{mL}$ LPS group, and there were statistically significant differences between these 2 groups $(\mathrm{P}<0.05)$. In the $1 \mu \mathrm{g} / \mathrm{mL}$ LPS $+10 \mu \mathrm{M} \mathrm{LY} 294002$
$+10 \mu \mathrm{M}$ PQQ group, LC3 was up-regulated compared with that in the $1 \mu \mathrm{g} / \mathrm{mL}$ LPS $+10 \mu \mathrm{M}$ LY294002 group, and the difference was statistically significant $(\mathrm{P}<0.05)$, as shown in Figure $7 B$. The expression of LAMP2 was increased in the $1 \mu \mathrm{g} / \mathrm{mL}$ LPS + $10 \mu \mathrm{M} \mathrm{LY} 294002+20 \mu \mathrm{M}$ PQQ group compared with that in the $1 \mu \mathrm{g} / \mathrm{mL}$ LPS $+10 \mu$ M LY294002 group, and the difference was statistically significant $(\mathrm{P}<0.05)$, as shown in Figure 7C. This suggested that after LY294002 inhibits the Akt signaling pathway, it does not completely block the role of PQQ in the upregulation of LPS-treated HAPI microglia in producing LC3 and LAMP2.

WB showed that compared with the $1 \mu \mathrm{g} / \mathrm{mL}$ LPS group, TNFR1 expression was decreased in the $1 \mu \mathrm{g} / \mathrm{mL}$ LPS + $10 \mu M$ LY294002 group, and the difference was statistically significant $(\mathrm{P}<0.05)$. There was no significant difference between the $1 \mu \mathrm{g} / \mathrm{mL}$ LPS + $10 \mu \mathrm{M}$ LY294002 + $10 \mu \mathrm{M}$ PQQ group and $1 \mu \mathrm{g} / \mathrm{mL}$ LPS + $10 \mu \mathrm{M} \mathrm{LY} 294002+$ $20 \mu \mathrm{M}$ PQQ group $(\mathrm{P}>0.05)$, as shown in Figure $7 D$.

The TNFR2 expression in the $1 \mu \mathrm{g} / \mathrm{mL}$ LPS $+10 \mu \mathrm{M}$ LY294002 group was not significantly different from that in the $1 \mu \mathrm{g} / \mathrm{mL}$ LPS group $(\mathrm{P}>0.05)$; the TNFR2 expression in the $1 \mu \mathrm{g} / \mathrm{mL}$ LPS + $10 \mu \mathrm{M}$ LY294002 + $10 \mu \mathrm{M}$ PQQ group was decreased compared with that in the $1 \mu \mathrm{g} / \mathrm{mL}$ LPS + $10 \mu$ M LY294002 group, and the difference were statistically significant $(\mathrm{P}<0.05)$, as shown in Figure $7 E$. This indicated that the inhibition of Akt affected the down-regulation of TNFR1 and up-regulation of TNFR2 of PQQ in LPS- 
A

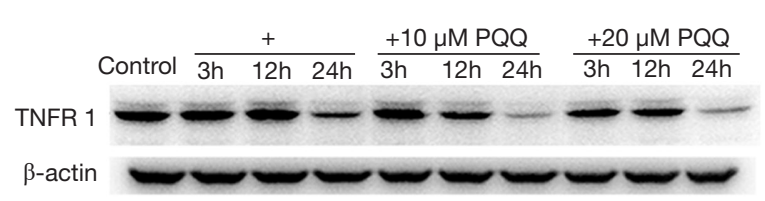

B

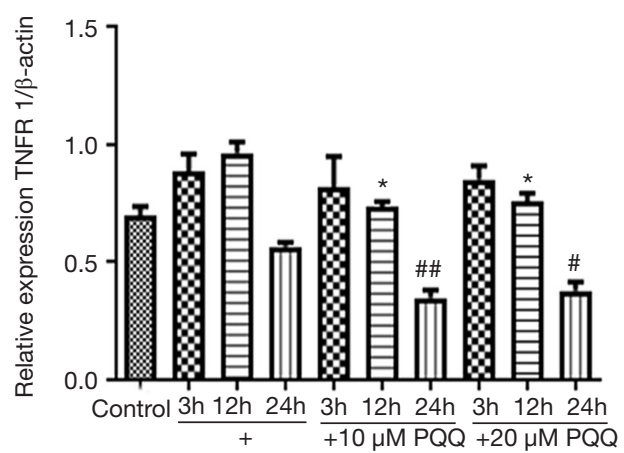

Hoechst
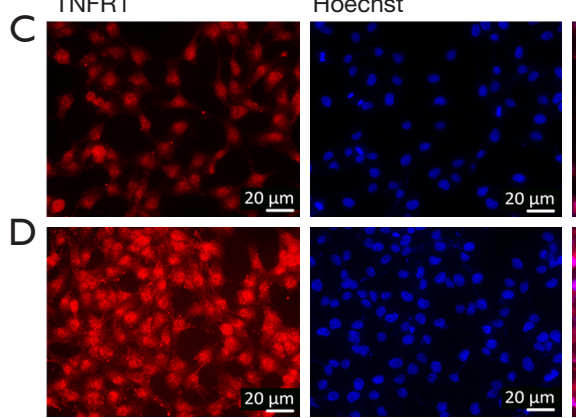

E

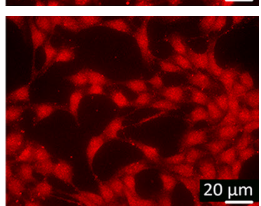

F

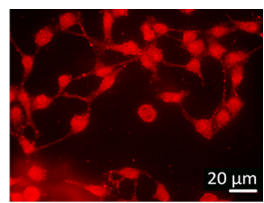

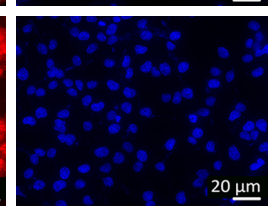
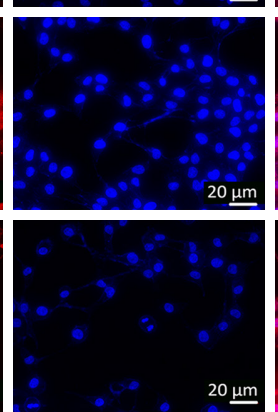

$[+] 1 \mu \mathrm{g} / \mathrm{ml}$ LPS

B'

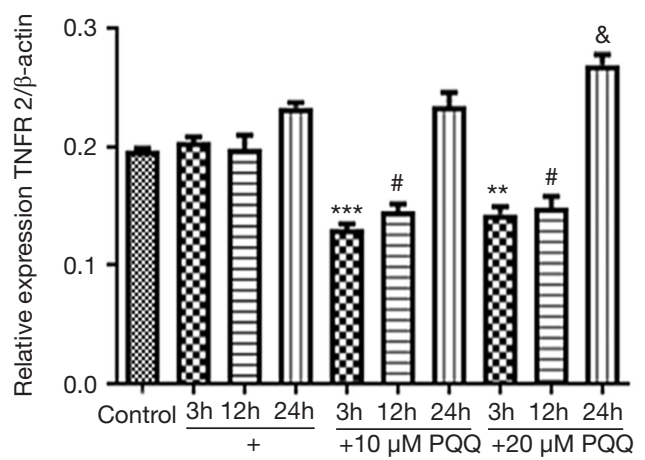

$A^{\prime}$ Control $\frac{+}{3 \mathrm{~h} 12 \mathrm{~h} 24 \mathrm{~h}} \frac{+10 \mu \mathrm{M} \mathrm{PQQ}}{3 \mathrm{~h} \quad 12 \mathrm{~h} 24 \mathrm{~h}} \frac{+20 \mu \mathrm{M} \mathrm{PQQ}}{3 \mathrm{~h} 12 \mathrm{~h} 24 \mathrm{~h}}$

TNFR 2 $\beta$-actin

$[+] 1 \mu g / m l$ LPS

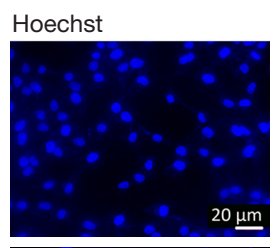

Merge
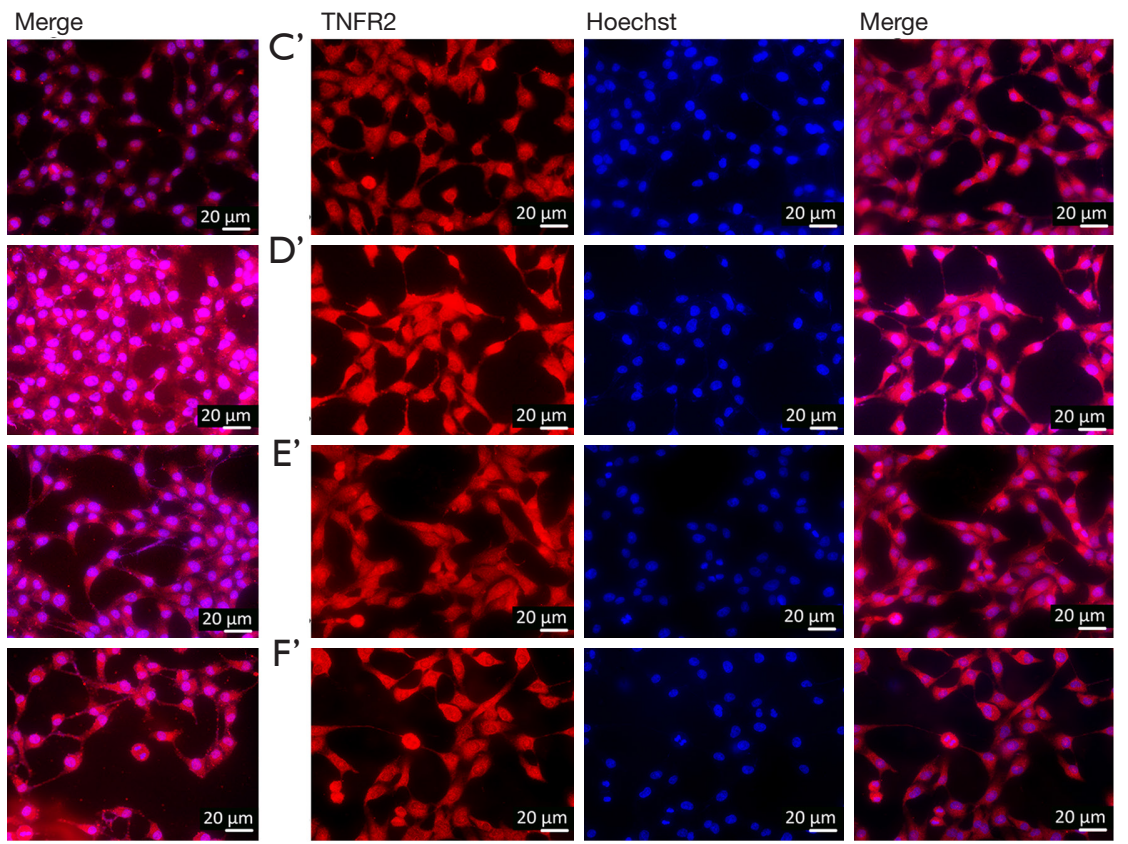

Figure 6 Expression of TNFR1 and TNFR2 in HAPI microglia. (A) WB detection of the protein expression of TNFR1 in different groups; (B) statistical graph of TNFR1/ $\beta$-actin. ${ }^{*} \mathrm{P}<0.05$ vs. $1 \mu \mathrm{g} / \mathrm{mL}$ LPS treatment for $12 \mathrm{~h} ;{ }^{*} \mathrm{P}<0.05$ vs. $1 \mu \mathrm{g} / \mathrm{mL}$ LPS treatment for $24 \mathrm{~h} ;{ }^{* \#} \mathrm{P}<0.01$ vs. $1 \mu \mathrm{g} / \mathrm{mL}$ LPS treatment for $24 \mathrm{~h}$. (A') WB detection of the protein expression of TNFR2 in different groups; (B') statistical graph of TNFR2/ $\beta$-actin. ${ }^{* *} \mathrm{P}<0.01$ vs. $1 \mu \mathrm{g} / \mathrm{mL}$ LPS treatment for $3 \mathrm{~h} ;{ }^{* * *} \mathrm{P}<0.001 v s .1 \mu \mathrm{g} / \mathrm{mL}$ LPS treatment for $3 \mathrm{~h} ;{ }^{*} \mathrm{P}<0.05 v s .1 \mu \mathrm{g} / \mathrm{mL}$ LPS treatment for $12 \mathrm{~h} ;{ }^{\circledR} \mathrm{P}<0.05$ vs. $1 \mu \mathrm{gg} / \mathrm{mL}$ LPS treatment for $24 \mathrm{~h}$. (A,B,A',B') from left to right are the control group (untreated), $1 \mu \mathrm{gg} / \mathrm{mL}$ LPS for $3 \mathrm{~h}, 1 \mu \mathrm{g} / \mathrm{mL}$ LPS for $12 \mathrm{~h}, 1 \mu \mathrm{g} / \mathrm{mL}$ LPS for $24 \mathrm{~h}, 1 \mu \mathrm{g} / \mathrm{mL}$ LPS $+10 \mu M$ PQQ for $3 \mathrm{~h}, 1 \mu \mathrm{g} / \mathrm{mL}$ LPS $+10 \mu M$ PQQ treatment $12 \mathrm{~h}, 1 \mu \mathrm{g} / \mathrm{mL}$ LPS $+10 \mu M$ PQQ treatment $24 \mathrm{~h}, 1 \mu \mathrm{g} / \mathrm{mL}$ LPS $+20 \mu M$ PQQ treatment $3 \mathrm{~h}, 1 \mu \mathrm{g} / \mathrm{mL}$ LPS $+20 \mu M$ PQQ treatment $12 \mathrm{~h}, 1 \mu \mathrm{g} / \mathrm{mL}$ LPS + $20 \mu \mathrm{M}$ PQQ treatment for $24 \mathrm{~h}$. (C-F) Immunofluorescence detection of TNFR1 expression in HAPI microglia. (C'-F') Immunofluorescence detection of TNFR2 expression in HAPI microglia. (C,C') control group; (D,D') $1 \mu \mathrm{g} / \mathrm{mL}$ LPS; (E,E') $1 \mu \mathrm{g} / \mathrm{mL}$ LPS + $10 \mu \mathrm{M}$ PQQ; (F,F') $1 \mu \mathrm{g} / \mathrm{mL}$ LPS + $20 \mu \mathrm{M}$ PQQ. TNFR1, TNFR2 (red); Hoechst (blue); Merge (combined picture); bar =20 $\mu \mathrm{m}$. PQQ, pyrroloquinoline quinone; WB, western blot; LPS, lipopolysaccharide. 
induced HAPI microglia.

\section{Effects of PQQ on the cell cycle of LPS-induced HAPI microglia}

The EdU proliferation assay detected the effect of PQQ on cell proliferation. As shown in Figure $7 F$, compared with the control group, $1 \mu \mathrm{g} / \mathrm{mL}$ LPS increased the proliferation rate of HAPI microglia cells $(\mathrm{P}<0.05)$. On the contrary, the proliferation rate of HAPI microglial cells in the PQQ groups was decreased, but there was no significant difference $(\mathrm{P}>0.05)$.

\section{Effect of PQQ on the migration of LPS-induced HAPI microglial cells}

Migratory activity is activated in microglial cells in response to CNS disease or injury. In the present study, scratch experiment (Figure $7 G$ ) and Transwell experiment (Figure $7 H$ ) were performed to determine the migration of HAPI microglial cells. The results showed that compared with the control group, $1 \mu \mathrm{g} / \mathrm{mL}$ LPS could induce the migration ability of HAPI microglial cells. The difference between these 2 groups was statistically significant $(\mathrm{P}<0.05)$. Compared with the LPS treatment group, an enhanced migration level of HAPI microglial cells was shown in the PQQ + LPS treatment groups, but there was no statistical difference (Figure $7 G, 7 H$ ).

\section{Effects of PQQ on the proliferation of LPS-induced HAPI microglia}

Cell proliferation is closely related to the cell cycle. In order to observe whether the effect of PQQ on HAPI microglial cell proliferation can be completed by influencing the cell cycle, flow cytometry was used to detect the cell cycle. The results showed that compared with the control group, the G1, G2, and S ratios in the $1 \mu \mathrm{g} / \mathrm{mL}$ LPS group and the $1 \mu \mathrm{g} / \mathrm{mL}$ LPS $+10 \mu \mathrm{M}$ PQQ group showed no statistically significant difference (all $\mathrm{P}>0.05$ ), as shown in Figure $7 I, 77$. These results suggest that cell cycle changes did not achieve the effect of PQQ on the proliferation of HAPI microglial cells.

\section{Discussion}

Most of the previous studies on the role of autophagy in immunity and inflammation have focused on macrophages or other types of cells, and little is known about the role and regulatory mechanism of autophagy in microglia. Our previous study found that brain injury could induce cell apoptosis, which could be reduced by using PQQ. In addition, the expression levels of LC3 and LAMP2 were also changed, suggesting that PQQ may be involved in apoptosis and autophagy caused by brain injury (40). Some researchers have described microRNA-mediated autophagy gene regulation in microglia cells. Both BECN1 and autophagy related protein 3 (ATG3) protein levels in LPS-treated BV-2 cells were significantly reduced $(41,42)$. Another study revealed autophagy damage in the brains of mice injected with LPS, which was demonstrated by a significant reduction in BECN1 and MAP1LC3b-II levels and an increase in sequestosome1 (SQSTM1/P62) in the cortex and hippocampus (43). However, none of these authors performed a cell-type specificity analysis. In the present study, we found that PQQ reduced LPS-induced apoptosis of HAPI microglia with increased autophagy level, enhanced lysosomal activity, and changed LAMP2 localization in cells. These results provided a new understanding of the neuroprotective mechanism of PQQ. It has been addressed in a recent paper $(10.3390 /$ ijms 21218382$)$ that the effects of PQQ are likely the combined actions of free PQQ and its derivatives. In addition, there is considerable evidence (44-46) that the transition from autophagy to apoptosis depends on the severity of stress. Autophagy is an early adaptive response before apoptosis, located upstream of apoptosis (47). It has been reported that activation of the autophagy pathway inhibited apoptosis and the expression of inducible nitric oxide synthase (iNOS) and interleukin 6 (IL-6) in BV2 cells (48). Protective autophagy can inhibit stress response and subsequent apoptosis (49), which is similar to the results of electron microscopy in this study, suggesting that PQQ can reduce the ER stress response of LPS-induced HAPI microglia. All these results indicated that PQQ is involved in the cross-talk between apoptosis and autophagy, which may change the fate of apoptosis by improving autophagy activity, and the mechanism needs further study. Other studies (28) have reported that the PI3K-Akt1-FoxO3 pathway plays an important role in the autophagy of LPS-induced microglia. In this study, the use of Akt inhibitor LY294002 resulted in decreased autophagy of LPS-induced microglia, and then reduced lysosomal activity, while PQQ alleviated the effect of the Akt inhibitor. These results suggested that the effect 

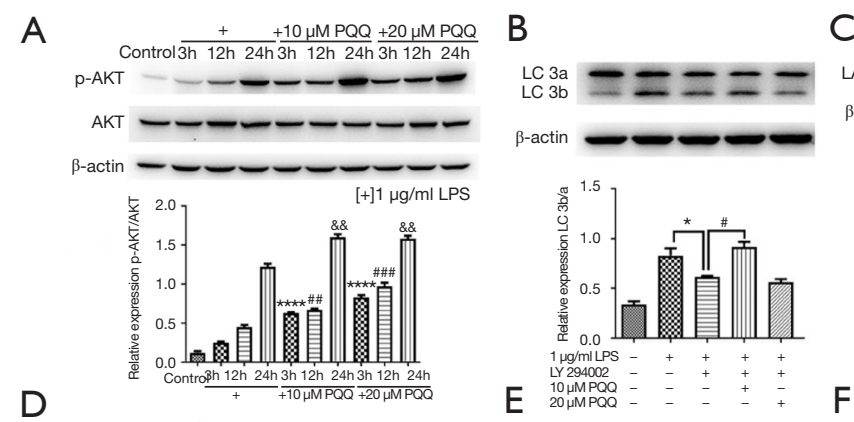

C

D

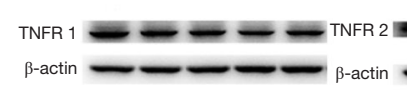

E
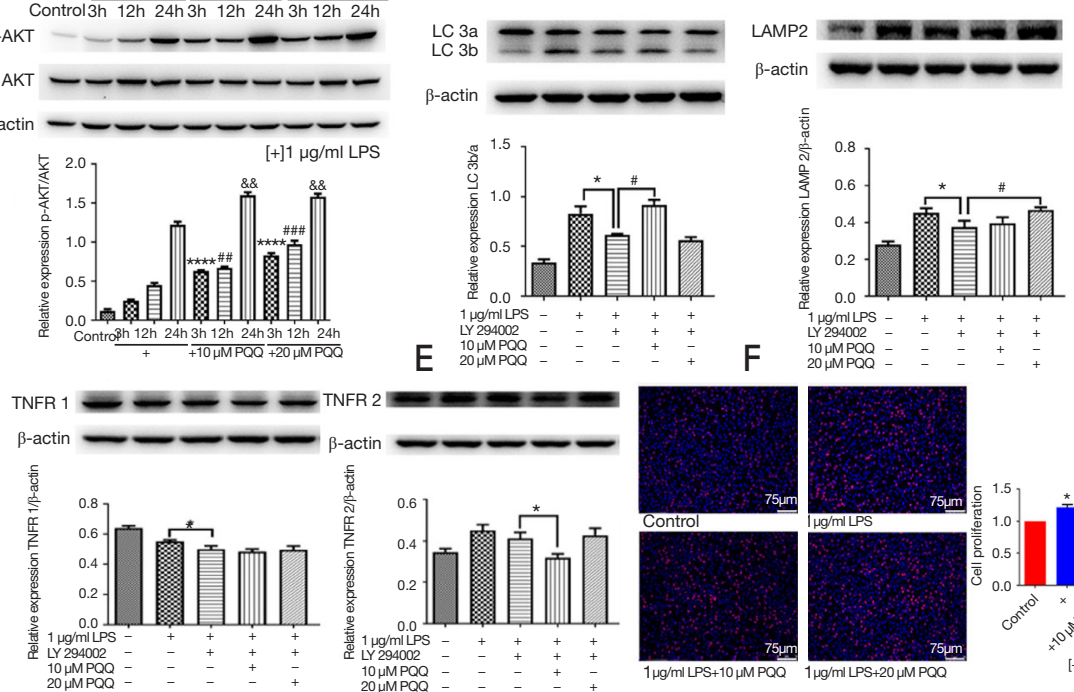

G $20 \mathrm{MM}$ PQQ
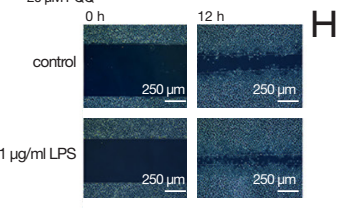

$\mathrm{H}$
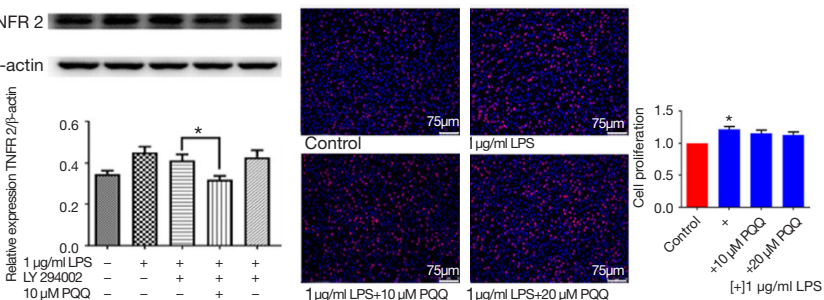

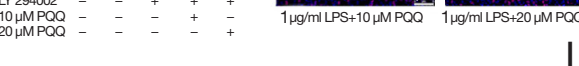
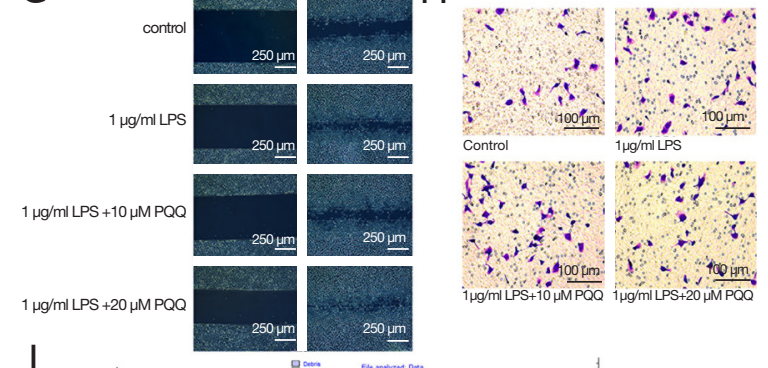

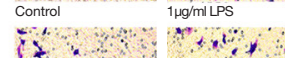
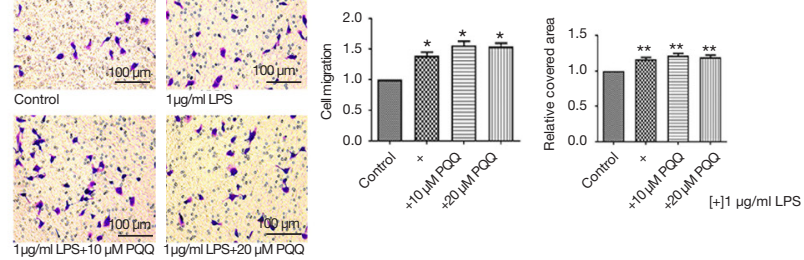

I
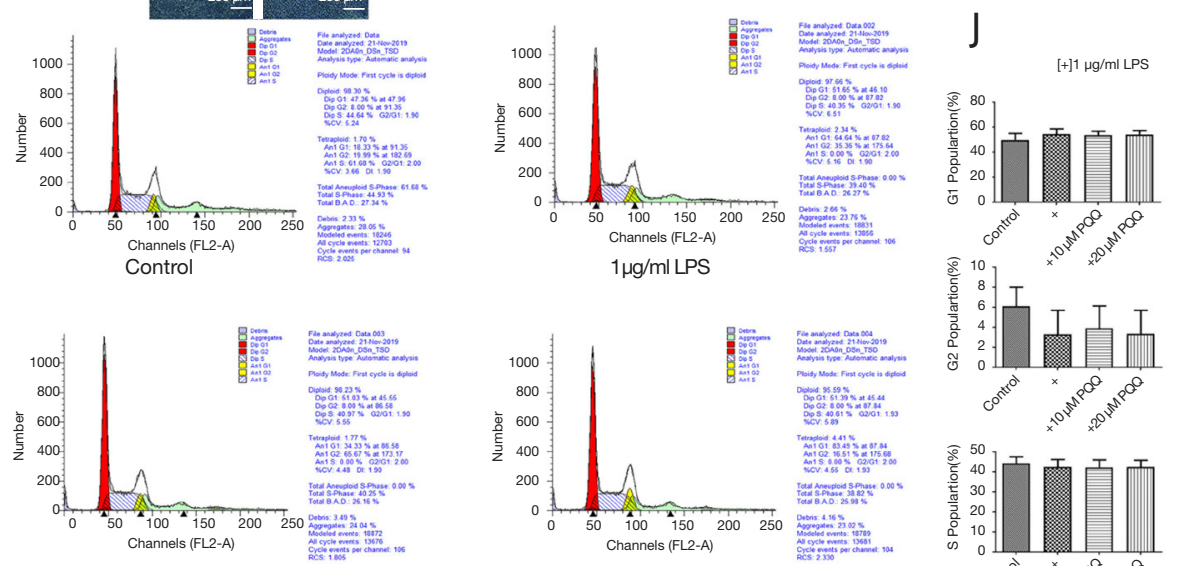

$1 \mu \mathrm{g} / \mathrm{ml} \mathrm{LPS}+20 \mu \mathrm{M}$ PQQ

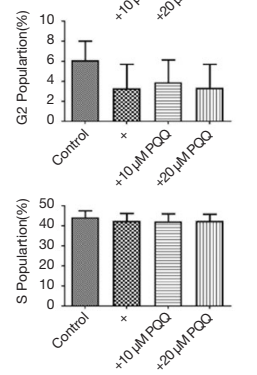

Figure 7 The effect of PQQ on PI3K-Akt signal pathway and its biological role in HAPI microglia. (A-E) WB detection of p-AKT/AKT (A), LC3b/a (B), LAMP2 (C), TNFR1 (D), and TNFR2 (E) protein expression in different groups. +: $1 \mu \mathrm{g} / \mathrm{mL}$ LPS; (A) from left to right are the control group (untreated), $1 \mu \mathrm{g} / \mathrm{mL}$ LPS treatment for $3 \mathrm{~h}, 1 \mu \mathrm{g} / \mathrm{mL}$ LPS treatment for $12 \mathrm{~h}, 1 \mu \mathrm{g} / \mathrm{mL}$ LPS treatment for $24 \mathrm{~h}, 1 \mu \mathrm{g} / \mathrm{mL}$ LPS $+10 \mu \mathrm{M}$ PQQ treatment for $3 \mathrm{~h}, 1 \mu \mathrm{g} / \mathrm{mL}$ LPS + $10 \mu \mathrm{M}$ PQQ treatment for $12 \mathrm{~h}, 1 \mu \mathrm{g} / \mathrm{mL}$ LPS + $10 \mu \mathrm{M}$ PQQ treatment for $24 \mathrm{~h}, 1 \mu \mathrm{g} / \mathrm{mL}$ LPS + $20 \mu \mathrm{M}$ PQQ treatment $3 \mathrm{~h}, 1 \mu \mathrm{g} / \mathrm{mL}$ LPS + $20 \mu \mathrm{M}$ PQQ treatment for $12 \mathrm{~h}, 1 \mu \mathrm{g} / \mathrm{mL}$ LPS $+20 \mu \mathrm{M}$ PQQ treatment for $24 \mathrm{~h} .{ }^{* * * *} \mathrm{P}<0.0001 v s .1 \mu \mathrm{g} / \mathrm{mL}$ LPS treatment for $3 \mathrm{~h}$; ${ }^{\# \#} \mathrm{P}<0.01 v s .1 \mu \mathrm{g} / \mathrm{mL}$ LPS

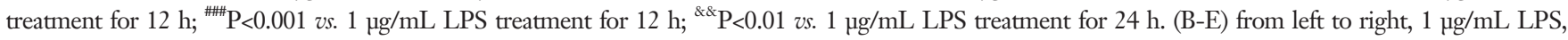
$1 \mu \mathrm{g} / \mathrm{mL}$ LPS + $10 \mu \mathrm{M}$ LY294002, $1 \mu \mathrm{g} / \mathrm{mL}$ LPS + $10 \mu \mathrm{M}$ LY294002 + $10 \mu \mathrm{M}$ PQQ, $1 \mu \mathrm{g} / \mathrm{mL}$ LPS + $10 \mu M$ LY294002 + $20 \mu M$ PQQ, treatment time 24 h; ${ }^{*} \mathrm{P}<0.05$ vs. $1 \mu \mathrm{g} / \mathrm{mL}$ LPS; ${ }^{*} \mathrm{P}<0.05$ vs. $1 \mu \mathrm{g} / \mathrm{mL}$ LPS $+10 \mu \mathrm{M}$ LY294002. (F) EdU detects the effect of PQQ on the proliferation of HAPI microglia, + , $1 \mu \mathrm{g} / \mathrm{mL}$ LPS, ${ }^{*} \mathrm{P}<0.05$ vs. control group, bar $=75 \mu \mathrm{m}$. Red: Apollo staining, blue: Hoechst 33342 stain the nucleus; (G,H) effect of PQQ on LPS-induced migration of HAPI microglia. (G) Scratch experiment, bar $=250 \mu \mathrm{m} ;(\mathrm{H})$ Transwell experiment, Crystal violet stain the nucleus, bar $=100 \mu \mathrm{m}$, ${ }^{* \star} \mathrm{P}<0.01 v s$. control group; ${ }^{*} \mathrm{P}<0.05$ vs. control group. (I, J) The cell cycle effect of PQQ on LPS-induced HAPI microglia by flow cytometry. (I) The results of flow cytometry; (J) statistical graphs of G1, G2, and S phases. PQQ, pyrroloquinoline quinone; WB, western blot; LPS, lipopolysaccharide. 
of PQQ on the autophagy of LPS-induced microglia was regulated through the PI3K-Akt pathway.

The TNF is an important factor in various acute and chronic neurodegenerative diseases and plays an important role in various neurodegenerative diseases. The antagonistic effects of 2 TNFRs in the CNS have been revealed in animal disease models: TNFR1 was associated with inflammatory degeneration and TNFR2 with neuroprotection (50-52). In a demyelinating mouse model induced by cuprizone (a toxin), TNFR2 was essential for oligodendrocyte regeneration, and TNF signaling via TNFR1 promoted nerve demyelination (50). Selective inhibition of TNFR1 and activation of TNFR2 showed great therapeutic potential in a mouse model of induced acute neurodegeneration (53). In this study, PQQ reduced the expression of TNFR1 in LPS-stimulated HAPI microglia, and PQQ decreased the expression of TNFR2 at 3 and $12 \mathrm{~h}$, but it was significantly upregulated at $24 \mathrm{~h}$. The principle of this needs to be further studied to clarify the relevant mechanism. To assess specific neurons of TNF and its receptors in retinal ischemia models, TNF deficiency does not affect the overall cell loss.

On the contrary, the absence of TNFR 1 in neurodegenerative strongly reduced cell numbers, and the lack of TNFR2 led to the increase of the neurodegenerative nerve associated with PI3K/Akt activation (37). Others have reported that TNFR2 mediates protection in vitro in a PI3K/Akt-dependent manner to prevent glutamate-induced cell death in cortical neurons $(50,52,54)$. These results are similar to our results that inhibition of Akt phosphorylation could reduce the ability of PQQ to produce TNFR2 in LPS-induced HAPI microglia.

The effect of PQQ on cell proliferation may depend on cell type. A report on the effect of PQQ on human SK-N-SH cells and HepG2 cells showed that the effect of PQQ on HepG2 cell proliferation was weaker than that on SK-N-SH cell proliferation (55). It has also been reported that PQQ induces fibroblast proliferation and increases nerve growth factor (NGF) (56). In this study, LPS stimulated cell proliferation, while the addition of PQQ did not significantly change cell proliferation. Flow cytometry analysis of the cell cycle showed that the number of cells in the G1, G2, and S stages was also not statistically significant. These results indicated that PQQ does not affect the cell cycle of HAPI microglial cells.

Microglia migrate during normal CNS development and through disease or injury in adulthood. Although their function depends on their activation state, which is itself regulated by a complex environment, microglia must migrate to the target site regardless of their activation state. In this study, LPS-treated microglial showed increased migration. This is inconsistent with previous reports, and although the reasons for this are unclear, the effects of LPS on migration may depend on species, strain, cell type, and age. The migration ability of newborn rats (57) and adult human microglia (58) as well as guinea pig peritoneal macrophages (59) and rabbit alveolar macrophages (60) has been shown to be weakened.

In contrast, some studies reported increased migration of LPS in RAW264.7 macrophage lines and primary rat peritoneal macrophages (61), but did not indicate LPS dose (61). Interestingly, peritoneal macrophage migration was mildly inhibited by LPS in LPS-sensitive mouse strains (C3H/HeN, C57BL10/S) but increased in LPS-resistant mice (C3H/HeJ, C57BL10/ScCr strains), although only exceeding $50 \mathrm{ng} / \mathrm{mL}$ at higher LPS doses (62). The effect of microglia age is also unknown. Rat microglia cells were studied using newborn mice (57), while macrophages were studied using adult animals. Another difficulty in comparing results was that the concentrations of LPS used were different from the strains, but earlier dose studies found that the same concentration $(10 \mathrm{ng} / \mathrm{mL})$ reduced the migration of primary peritoneal macrophages in guinea pigs by $56 \%$ (59). In this study, PQQ use did not significantly increase the migratory ability of microglia.

Previous studies of autophagy in the CNS have focused mainly on neurons without considering the potential consequences of autophagy regulation in glial cells (including microglia). In this study, the effect of PQQ on autophagy and apoptosis of LPS-induced HAPI microglia and related mechanisms may help to elucidate its neuroprotective effect and its role in health and disease.

In conclusion, PQQ reduces the apoptosis of LPSinduced HAPI microglia by increasing the autophagy level and changes the distribution of LAMP2 in cells to enhance lysosomal activity, which is regulated through the PI3K/Akt signaling pathway.

\section{Acknowledgments}

We thank Dr. Waleed Hussein (School of Chemistry and Molecular Biosciences, The University of Queensland, Brisbane QLD 4072 Australia) for initial editing of the paper's language and https://app.grammarly.com/ for language checker assistance.

Funding: This work was supported by the National Natural 
Scientific Foundation of China (31370803), the Public Health Program of Nantong City (MS22019001), Science and Technology Program of Zhangjiagang City (ZKS1930).

\section{Footnote}

Reporting Checklist: The authors have completed the MDAR reporting checklist. Available at https://dx.doi. org/10.21037/atm-21-730

Data Sharing Statement: Available at https://dx.doi. org/10.21037/atm-21-730

Peer Review File: Available at https://dx.doi.org/10.21037/ atm-21-730

Conflicts of Interest: All authors have completed the ICMJE uniform disclosure form (available at https://dx.doi. org/10.21037/atm-21-730). The authors have no conflicts of interest to declare.

Ethical Statement: All authors are accountable for all aspects of the work in ensuring that questions related to the accuracy or integrity of any part of the work are appropriately investigated and resolved. For all illustrations, including recognizable individuals, living or deceased, great care was taken to ensure that consent for publication was given.

Open Access Statement: This is an Open Access article distributed in accordance with the Creative Commons Attribution-NonCommercial-NoDerivs 4.0 International License (CC BY-NC-ND 4.0), which permits the noncommercial replication and distribution of the article with the strict proviso that no changes or edits are made and the original work is properly cited (including links to both the formal publication through the relevant DOI and the license). See: https://creativecommons.org/licenses/by-nc-nd/4.0/.

\section{References}

1. Salisbury SA, Forrest HS, Cruse WB, et al. A novel coenzyme from bacterial primary alcohol dehydrogenases. Nature 1979;280:843-4.

2. Rucker R, Chowanadisai W, Nakano M. Potential physiological importance of pyrroloquinoline quinone. Altern Med Rev 2009;14:268-77.

3. Stites TE, Mitchell AE, Rucker RB. Physiological importance of quinoenzymes and the O-quinone family of cofactors. J Nutr 2000;130:719-27.

4. Akagawa M, Minematsu K, Shibata T, et al. Identification of lactate dehydrogenase as a mammalian pyrroloquinoline quinone (PQQ)-binding protein. Sci Rep 2016;6:26723.

5. Chowanadisai W, Bauerly KA, Tchaparian E, et al. Pyrroloquinoline quinone stimulates mitochondrial biogenesis through cAMP response element-binding protein phosphorylation and increased PGC-1alpha expression. J Biol Chem 2010;285:142-52.

6. Killgore J, Smidt C, Duich L, et al. Nutritional importance of pyrroloquinoline quinone. Science 1989;245:850-2.

7. Kasahara T, Kato T. Nutritional biochemistry: A new redox-cofactor vitamin for mammals. Nature 2003;422:832.

8. Rucker R, Storms D, Sheets A, et al. Biochemistry: is pyrroloquinoline quinone a vitamin? Nature 2005;433:E10-1; discussion E11-2.

9. Yorimitsu T, Klionsky DJ. Autophagy: molecular machinery for self-eating. Cell Death Differ 2005;12 Suppl 2:1542-52.

10. Batista CRA, Gomes GF, Candelario-Jalil E, et al. Lipopolysaccharide-Induced Neuroinflammation as a Bridge to Understand Neurodegeneration. Int J Mol Sci 2019;20:2293.

11. Ransohoff RM. How neuroinflammation contributes to neurodegeneration. Science 2016;353:777-83.

12. Jahn H. Memory loss in Alzheimer's disease. Dialogues Clin Neurosci 2013;15:445-54.

13. Gray SC, Kinghorn KJ, Woodling NS. Shifting equilibriums in Alzheimer's disease: the complex roles of microglia in neuroinflammation, neuronal survival and neurogenesis. Neural Regen Res 2020;15:1208-19.

14. Cookson MR. alpha-Synuclein and neuronal cell death. Mol Neurodegener 2009;4:9.

15. Decressac M, Mattsson B, Weikop P, et al. TFEBmediated autophagy rescues midbrain dopamine neurons from $\alpha$-synuclein toxicity. Proc Natl Acad Sci U S A 2013;110:E1817-26.

16. Yang W, Yu S. Synucleinopathies: common features and hippocampal manifestations. Cell Mol Life Sci 2017;74:1485-501.

17. Martinez J, Almendinger J, Oberst A, et al. Microtubuleassociated protein 1 light chain 3 alpha (LC3)-associated phagocytosis is required for the efficient clearance of dead cells. Proc Natl Acad Sci U S A 2011;108:17396-401.

18. Boyle KB, Randow F. Rubicon swaps autophagy for LAP. Nat Cell Biol 2015;17:843-5.

19. Delgado MA, Elmaoued RA, Davis AS, et al. Toll-like 
receptors control autophagy. EMBO J 2008;27:1110-21.

20. Kawasaki T, Kawai T. Toll-like receptor signaling pathways. Front Immunol 2014;5:461.

21. Waltz P, Carchman EH, Young AC, et al. Lipopolysaccaride induces autophagic signaling in macrophages via a TLR4, heme oxygenase- 1 dependent pathway. Autophagy 2011;7:315-20.

22. Chen C, Deng M, Sun Q, et al. Lipopolysaccharide stimulates p62-dependent autophagy-like aggregate clearance in hepatocytes. Biomed Res Int 2014;2014:267350.

23. Wang J, Feng X, Zeng Y, et al. Lipopolysaccharide (LPS)-induced autophagy is involved in the restriction of Escherichia coli in peritoneal mesothelial cells. BMC Microbiol 2013;13:255.

24. Saijo K, Glass CK. Microglial cell origin and phenotypes in health and disease. Nat Rev Immunol 2011;11:775-87.

25. Plaza-Zabala A, Sierra-Torre V, Sierra A. Autophagy and Microglia: Novel Partners in Neurodegeneration and Aging. Int J Mol Sci 2017;18:598.

26. Salter MW, Stevens B. Microglia emerge as central players in brain disease. Nat Med 2017;23:1018-27.

27. Cho MH, Cho K, Kang HJ, et al. Autophagy in microglia degrades extracellular $\beta$-amyloid fibrils and regulates the NLRP3 inflammasome. Autophagy 2014;10:1761-75.

28. Lee JW, Nam H, Kim LE, et al. TLR4 (toll-like receptor 4) activation suppresses autophagy through inhibition of FOXO3 and impairs phagocytic capacity of microglia. Autophagy 2019;15:753-70.

29. Tartaglia LA, Ayres TM, Wong GH, et al. A novel domain within the $55 \mathrm{kd}$ TNF receptor signals cell death. Cell 1993;74:845-53.

30. Park HH, Lo YC, Lin SC, et al. The death domain superfamily in intracellular signaling of apoptosis and inflammation. Annu Rev Immunol 2007;25:561-86.

31. Wajant H, Pfizenmaier K, Scheurich P. Tumor necrosis factor signaling. Cell Death Differ 2003;10:45-65.

32. Brenner D, Blaser H, Mak TW. Regulation of tumour necrosis factor signalling: live or let die. Nat Rev Immunol 2015;15:362-74.

33. Xie P. TRAF molecules in cell signaling and in human diseases. J Mol Signal 2013;8:7.

34. Medler J, Wajant H. Tumor necrosis factor receptor-2 (TNFR2): an overview of an emerging drug target. Expert Opin Ther Targets 2019;23:295-307.

35. Pauli U. Control of tumor necrosis factor gene expression. Crit Rev Eukaryot Gene Expr 1994;4:323-44.
36. Fontaine V, Mohand-Said S, Hanoteau N, et al. Neurodegenerative and neuroprotective effects of tumor Necrosis factor (TNF) in retinal ischemia: opposite roles of TNF receptor 1 and TNF receptor 2. J Neurosci 2002;22:RC216.

37. Kumazawa T, Hiwasa T, Takiguchi M, et al. Activation of Ras signaling pathways by pyrroloquinoline quinone in NIH3T3 mouse fibroblasts. Int J Mol Med 2007;19:765-70.

38. Kimura K, Takada M, Ishii T, et al. Pyrroloquinoline quinone stimulates epithelial cell proliferation by activating epidermal growth factor receptor through redox cycling. Free Radic Biol Med 2012;53:1239-51.

39. Naito Y, Kumazawa T, Kino I, et al. Effects of pyrroloquinoline quinone (PQQ) and PQQ-oxazole on DNA synthesis of cultured human fibroblasts. Life Sci 1993;52:1909-15.

40. Zhang P, Ye Y, Qian Y, et al. The Effect of Pyrroloquinoline Quinone on Apoptosis and Autophagy in Traumatic Brain Injury. CNS Neurol Disord Drug Targets 2017;16:724-36.

41. Song J, Oh Y, Lee JE. miR-Let7A Modulates Autophagy Induction in LPS-Activated Microglia. Exp Neurobiol 2015;24:117-25.

42. François A, Terro F, Quellard N, et al. Impairment of autophagy in the central nervous system during lipopolysaccharide-induced inflammatory stress in mice. Mol Brain 2014;7:56.

43. Han HE, Kim TK, Son HJ, et al. Activation of Autophagy Pathway Suppresses the Expression of iNOS, IL6 and Cell Death of LPS-Stimulated Microglia Cells. Biomol Ther (Seoul) 2013;21:21-8.

44. Zhao GX, Pan H, Ouyang DY, et al. The critical molecular interconnections in regulating apoptosis and autophagy. Ann Med 2015;47:305-15.

45. Fan YJ, Zong WX. The cellular decision between apoptosis and autophagy. Chin J Cancer 2013;32:121-9.

46. Liu Y, Yang B, Zhang L, et al. Ginkgolic acid induces interplay between apoptosis and autophagy regulated by ROS generation in colon cancer. Biochem Biophys Res Commun 2018;498:246-53.

47. Kouroku Y, Fujita E, Tanida I, et al. ER stress (PERK/ eIF2alpha phosphorylation) mediates the polyglutamineinduced LC3 conversion, an essential step for autophagy formation. Cell Death Differ 2007;14:230-9.

48. Radogna F, Dicato M, Diederich M. Cancer-type-specific crosstalk between autophagy, necroptosis and apoptosis as a pharmacological target. Biochem Pharmacol 2015;94:1-11. 
49. Probert L. TNF and its receptors in the CNS: The essential, the desirable and the deleterious effects. Neuroscience 2015;302:2-22.

50. Fischer R, Maier O, Siegemund M, et al. A TNF receptor 2 selective agonist rescues human neurons from oxidative stress-induced cell death. PLoS One 2011;6:e27621.

51. Maier O, Fischer R, Agresti C, et al. TNF receptor 2 protects oligodendrocyte progenitor cells against oxidative stress. Biochem Biophys Res Commun 2013;440:336-41.

52. Dong Y, Fischer R, Naudé PJ, et al. Essential protective role of tumor necrosis factor receptor 2 in neurodegeneration. Proc Natl Acad Sci U S A 2016;113:12304-9.

53. Dolga AM, Granic I, Blank T, et al. TNF-alpha-mediates neuroprotection against glutamate-induced excitotoxicity via NF-kappaB-dependent up-regulation of K2.2 channels. J Neurochem 2008;107:1158-67.

54. Yamada Y, Nishii K, Kuwata K, et al. Effects of pyrroloquinoline quinone and imidazole pyrroloquinoline on biological activities and neural functions. Heliyon 2020;6:e03240.

55. De Simone R, Niturad CE, De Nuccio C, et al. TGF- $\beta$ and LPS modulate ADP-induced migration of microglial cells through $\mathrm{P} 2 \mathrm{Y} 1$ and $\mathrm{P} 2 \mathrm{Y} 12$ receptor expression. J Neurochem 2010;115:450-9.

56. Yamaguchi K, Sasano A, Urakami T, et al. Stimulation of nerve growth factor production by pyrroloquinoline quinone and its derivatives in vitro and in vivo. Biosci

Cite this article as: Gao S, Zhou Q, Jin H, Shi N, Wang X, Zhang L, Yan M. Effect of pyrroloquinoline quinone on lipopolysaccharide-induced autophagy in HAPI microglia cells. Ann Transl Med 2021;9(17):1377. doi: 10.21037/atm-21-730
Biotechnol Biochem 1993;57:1231-3.

57. Broderick C, Duncan L, Taylor N, et al. IFN-gamma and LPS-mediated IL-10-dependent suppression of retinal microglial activation. Invest Ophthalmol Vis Sci 2000;41:2613-22.

58. Nagao S, Tanaka A, Onozaki K, et al. Differences between macrophage migration inhibitions by lymphokines and muramyl dipeptide (MDP) or lipopolysaccharide (LPS): migration enhancement by lymphokines. Cell Immunol 1982;71:1-11.

59. Gordon MR, Chida K, Takata I, et al. Macrophage migration inhibition induced by MDP, LPS, PMA, and MIF/MAF: reversal by macrophage migration enhancement factor (MEF), L-fucose, L-fucosyl BSA, D-mannose, and D-mannosyl BSA. J Leukoc Biol 1987;42:197-203.

60. Maa MC, Chang MY, Hsieh MY, et al. Butyrate reduced lipopolysaccharide-mediated macrophage migration by suppression of Src enhancement and focal adhesion kinase activity. J Nutr Biochem 2010;21:1186-92.

61. Tajima T, Murata T, Aritake K, et al. Lipopolysaccharide induces macrophage migration via prostaglandin $\mathrm{D}(2)$ and prostaglandin E(2). J Pharmacol Exp Ther 2008;326:493-501.

62. Verghese MW, Snyderman R. Endotoxin (LPS) stimulates in vitro migration of macrophages from LPS-resistant mice but not from LPS-sensitive mice. J Immunol 1982;128:608-13. 